\title{
Numb is Required for the Production of Terminal Asymmetric Cell Divisions in the Developing Mouse Retina
}

\author{
Amel Kechad, ${ }^{1,2 \star}$ Christine Jolicoeur, ${ }^{1 \star}$ Adele Tufford, ${ }^{1}$ Pierre Mattar, ${ }^{1}$ Renee W.Y. Chow, ${ }^{3}$ William A. Harris, ${ }^{3}$ \\ and Michel Cayouette $\mathrm{e}^{1,2,4}$ \\ ${ }^{1}$ Cellular Neurobiology Research Unit, Institut de recherches cliniques de Montréal (IRCM), Montreal, Quebec H2W 1R7, Canada, ${ }^{2}$ Department of Anatomy \\ and Cell Biology, McGill University, Montreal, Quebec H3A 2B2, Canada, ${ }^{3}$ Department of Physiology, Development and Neuroscience, University of \\ Cambridge, Cambridge CB2 3DY, United Kingdom, and ${ }^{4}$ Département de Médecine, Université de Montréal, Montreal, Quebec H3T 1P1, Canada
}

In the developing nervous system, cell diversification depends on the ability of neural progenitor cells to divide asymmetrically to generate daughter cells that acquire different identities. While much work has recently focused on the mechanisms controlling selfrenewing asymmetric divisions producing a differentiating daughter and a progenitor, little is known about mechanisms regulating how distinct differentiating cell types are produced at terminal divisions. Here we study the role of the endocytic adaptor protein Numb in the developing mouse retina. Using clonal numb inactivation in retinal progenitor cells (RPCs), we show that Numb is required for normal cell-cycle progression at early stages, but is dispensable for the production of self-renewing asymmetric cell divisions. At late stages, however, Numb is no longer required for cell-cycle progression, but is critical for the production of terminal asymmetric cell divisions. In the absence of Numb, asymmetric terminal divisions that generate a photoreceptor and a non-photoreceptor cell are decreased in favor of symmetric terminal divisions generating two photoreceptors. Using live imaging in retinal explants, we show that a Numb fusion protein is asymmetrically inherited by the daughter cells of some late RPC divisions. Together with our finding that Numb antagonizes Notch signaling in late-stage RPCs, and that blocking Notch signaling in late RPCs almost completely abolishes the generation of terminal asymmetric divisions, these results suggest a model in which asymmetric inheritance of Numb in sister cells of terminal divisions might create unequal Notch activity, which in turn drives the production of terminal asymmetric divisions.

\section{Introduction}

The process of asymmetric cell division, in which a dividing mother cell segregates cell-fate determinants asymmetrically into only one of the two daughter cells, plays an important part in cell diversification (Knoblich, 2008; Zhong and Chia, 2008; Siller and Doe, 2009), but little is known about this process in vertebrates (Götz and Huttner, 2005; Huttner and Kosodo, 2005; Farkas and Huttner, 2008; Fish et al., 2008; Zhong and Chia, 2008). In Drosophila, the endocytic adaptor protein Numb segregates asymmetrically in different neural progenitors and allows the two daughter cells to adopt distinct fates (for review, see Jan and Jan, 2001; Cayouette and Raff, 2002; Betschinger and Knoblich, 2004;

Received Aug. 25, 2012; revised 0ct. 4, 2012; accepted 0ct. 5, 2012.

Author contributions: M.C. designed research; A.K., C.J., A.T.,P.M., and R.W.C. performed research; A.K., C.J.,A.T. P.M., R.W.Y.C., W.A.H., and M.C. analyzed data; W.A.H. and M.C. wrote the paper.

This work was supported by grants from the Canadian Institutes of Health Research (CIHR) and the Foundation Fighting Blindness - Canada. M.C. is a fellow of the Fonds de la recherche en santé du Québec (FRSQ) and a W.K. Stell Scholar of the Foundation Fighting Blindness - Canada. We thank Diane Gingras for expert technical assistance with immunogold electron microscopy and Jessica Barthe for care and maintenance of the animal colony. We are grateful to Frédéric Charron and Artur Kania for insightful comments on this manuscript, Keith Murai for the f-GFP vector, C. Kintner for the tMam construct, and David Solecki for the Numb::Venus vector.

*A.K. and C.J. contributed equally to this work.

The authors declare no competing financial interests.

Correspondence should be addressed to Michel Cayouette, IRCM, 110, Ave des Pins Ouest, Montreal, QC H2W 1R7, Canada. E-mail:michel.cayouette@ircm.qc.ca.

DOI:10.1523/JNEUROSCI.4127-12.2012

Copyright $\odot 2012$ the authors $\quad 0270-6474 / 12 / 3217197-14 \$ 15.00 / 0$
Roegiers and Jan, 2004), apparently by antagonizing Notch signaling (Guo et al., 1996; Spana and Doe, 1996).

The function of the mammalian ortholog of Numb is not as clearly defined, but different conditional gene inactivation experiments of both Numb and its functional homolog Numblike in mouse cortical progenitors suggested an important role in neurogenesis. In some conditional knock-out experiments, precocious neuronal differentiation and rapid depletion of the progenitor pool were observed (Petersen et al., 2002, 2004), whereas in others, progenitor overproliferation and delayed cell-cycle exit were observed (Li et al., 2003). The reasons for these contrasting results remain unclear but might involve a changing role for Numb/Numblike over time, or differential functions in specific populations of progenitors. Despite the apparent differences in their reported findings, both groups suggested that Numb might normally function to promote self-renewing asymmetric cell divisions that generate a progenitor and a differentiating cell (P/D divisions), either by promoting the progenitor or neuronal fate. In these reports, terminal divisions that generate two neurons ( $D / D$ divisions) were considered "symmetric." Clearly, however, such terminal divisions can be asymmetric if the two daughter cells adopt different neuronal fates $\left(\mathrm{D}_{\mathrm{x}} / \mathrm{D}_{\mathrm{y}}\right.$ divisions) (Cayouette et al., 2006), but whether Numb inactivation affected production of terminal asymmetric divisions in the developing cortex in vivo was not explored.

Different lineage-tracing studies in the developing retina have shown that asymmetric terminal divisions occur during develop- 
ment, because two-cell clones were sometimes composed of differentiated cells of distinct types (Turner and Cepko, 1987; Holt et al., 1988; Turner et al., 1990). More recently, it was shown that retinal progenitor cells (RPCs) expressing the Olig2 transcription factor are biased to undergo a terminal division, with the type of neurons produced varying according to the time at which the division takes place (Hafler et al., 2012). Thus, Olig2 RPCs are highly reminiscent of Drosophila ganglion mother cells, where asymmetric inheritance of fate determinants regulates the binary outcome of their division (for review, see Knoblich, 2008; Zhong and Chia, 2008). Whether this mechanism is used by RPCs to regulate the asymmetric outcome of terminal divisions, however, remains unknown. Here, we hypothesize that asymmetric inheritance of Numb might have this role in terminal RPC divisions.

Using spatiotemporal-specific gene inactivation in RPCs, we report that Numb function changes over time during retinogenesis, regulating cell-cycle progression early and terminal asymmetric divisions late. Live imaging and gene expression analysis suggest a model in which asymmetric inheritance of Numb in terminal divisions might create unequal Notch signaling activity in sibling cells, inducing them to acquire distinct fates.

\section{Materials and Methods}

Animals. All animal work was performed in accordance to the Canadian Council on Animal Care guidelines. CD1, numb ${ }^{\text {flox/flox }}$; numblike $e^{\text {flox/flox }}$ (Wilson et al., 2007) (obtained from The Jackson Laboratory), the $\alpha$-Cre lines (Kammandel et al., 1999), and Sprague Dawley rats (Charles River) of either sex were used in this study.

Immunostainings and cell-cycle analysis. Primary antibodies used for immunofluorescence were as follows: activated Caspase-3 (1:100; Millipore Bioscience Research Reagents), atypical protein kinase C (PKC ; 1:200; Santa Cruz Biotechnology), $\beta$-galactosidase (1:200; Rockland), Brn3 (1:200; Santa Cruz Biotechnology), glutamine synthetase (1:200; BD Transduction Laboratories), Islet-1 (1:200; produced by Tom Jessell and distributed by the Developmental Studies Hybridoma Bank), Ki67 (1:200; Neo Markers), Lim-1 (1:1000; from T. Jessell, Columbia University), Numb (1:100; Abcam; this antibody also recognizes Numblike (NbL), but with less affinity than Numb), Par-3 (1:200; Millipore Biotech), phospho histone-H3 (PH3; 1:200, Millipore Biotech), protein kinase C $\alpha$ (PKC $\alpha ; 1: 200$; Santa Cruz Biotechnology), Pax-6 (1:200; Chemicon), rhodopsin (1:200; from R. Molday, University of British Columbia), BrdU (1:100; Dako), proliferating cell nuclear antigen (PCNA; 1:100; Santa Cruz Biotechnology) ZO-1 (1:200; Zymed). In vivo $\mathrm{BrdU}$ incorporation was done by intraperitoneal injection of BrdU (100 $\mathrm{mg}$ of $\mathrm{BrdU} / \mathrm{kg}$ ). For immunogold electron microscopy, retinas were fixed in $1 \%$ glutaraldehyde, postfixed with $1 \%$ osmium tetroxide, and embedded in LR White medium. Postembedding immunostaining for Numb was done with a 1:100 dilution of the antibody and secondary antibodies coupled to gold particles.

Cell-cycle time was estimated by incubating retinas for $2 \mathrm{~h}$ in BrdU, and then $30 \mathrm{~min}$ in 5-ethynyl-2' -deoxyuridine (EdU). Retinas were then fixed in $4 \%$ paraformaldehyde, sectioned, and stained for BrdU, EdU, and PCNA. The cell-cycle time in hours was calculated using the following formula: $2 \mathrm{~h} \times(\mathrm{PCNA}+$ cells/BrdU + only cells $)$, as described in Das et al., 2009.

In situ hybridization and $q R T$-PCR. Digoxigenin-labeled RNA probes were synthesized by PCR amplification from mouse brain CDNA library using the following primers: 5'-TCC CTC TGA AGC TGA CCG-3' and $5^{\prime}$-CCC TTG CTG GAC TGT GCT- 3 ' for the Numb probe and 5 '-CTT GCA GAA GAC CTT CGA GAT-3' and 5' -CCG ACA TGA GGT AAC AGA GTC-3' for the Numblike probe. Eyes were collected and frozen immediately in OCT, sectioned, air-dried for $30 \mathrm{~min}$, and fixed in PFA $4 \%$ for $20 \mathrm{~min}$. Sections were then digested with $2 \mu \mathrm{g} / \mathrm{ml}$ proteinase $\mathrm{K}$ at room temperature for $20 \mathrm{~min}$. Hybridization was done at $65^{\circ} \mathrm{C}$ overnight with $300 \mathrm{ng} / \mathrm{ml}$ RNA probes in the hybridization buffer (50\% formamide, $5 \times$ saline-sodium citrate, $5 \times$ Denhardt's, $5 \mathrm{mg} / \mathrm{ml}$ Torula RNA, $500 \mu \mathrm{g} / \mathrm{ml}$ fish sperm DNA). The probes were detected with an alkaline phosphatase-conjugated anti-Dig antibody (1:3500; Roche). The AP activity was revealed using the 4-nitro blue tetrazolium chloride (NBT/ BCIP; Roche).

For qRT-PCR, standard procedures were followed using the following primers: GAPDH-F: TGCAGCGGCAAAGTGGAGAT; GAPDH-R: ACTG TGCCGTTGAATTTGCC, Hes5-F: AGCTACCTGAAACACAGCAAAG CC; Hes5-R: TAAAGCAGCTTCATCTGCGTGTCG, and the following Quantitec primers (Qiagen): Numb (cat\# QT00097328), Hes1 (cat\# QT00313537), Heyl (cat\# QT00115094), RBPj (cat\# QT01744421).

Quantitative analysis. The number of cells expressing the different cell-type-specific markers was quantified by averaging the number of positive cells from three regions of $250-500 \mu \mathrm{m}$ in the peripheral retina at the level of the optic nerve for each animal. The proportions obtained were adjusted relative to control littermates to avoid small differences of developmental stages between litters. Statistical comparisons were done using Student's $t$ test.

Retinal explants and dissociated retinal cell culture. For in vitro experiments, retinal explants and dissociated cell cultures were prepared as previously described (Cayouette et al., 2001, 2003). For dissociated cell cultures, 150,000 cells were plated and cultured on $13 \mathrm{~mm}$ glass coverslips coated with poly-D-lysine $(10 \mu \mathrm{g} / \mathrm{ml})$ and laminin $(10 \mu \mathrm{g} / \mathrm{ml})$.

Retroviral vector constructions and production. Retroviral vectors were constructed by cloning Cre-recombinase, Numb p65, or tMam, a truncated version of mastermind (kind gift from C. Kintner), into a retroviral vector encoding placental alkaline phosphatase (PLAP) (Gaiano et al., 1999) or the Mixie-GFP (kindly provided by Dr. R. Bremner) vectors. The Numb::Venus fusion is in the pCX retroviral vector (kindly provided by D. Solecki). Retroviral stocks were prepared in Phoenix packaging cell line and purified as previously described (Cayouette and Raff, 2003).

Clonal analysis. Retinal explants in culture were infected with retroviral vectors and cultured for $2-17 \mathrm{~d}$, changing the medium every $2 \mathrm{~d}$. The explants were then fixed in $4 \%$ paraformaldehyde, cryoprotected in $20 \%$ sucrose, embedded in OCT, frozen, and sectioned at $25 \mu \mathrm{m}$ with a cryostat. For the detection of AP activity, retinal sections were first fixed in paraformaldehyde $4 \%$ for $1 \mathrm{~h}$ and then immersed in PBS at $65^{\circ} \mathrm{C}$ for $1 \mathrm{~h}$. The sections were then immersed in a solution of NBT/BCIP (Roche) at $37^{\circ} \mathrm{C}$ until desired level of staining was achieved. Clones of retinal cells were analyzed by counting the number of each cell type present in radial clusters, using morphology, position in the cell layers and expression of specific markers to identify the different cell types, as we previously described (Elliott et al., 2008).

Retinal electroporations. Plasmid DNA-encoding farnesylated GFP (f-GFP; Invitrogen) was diluted at $5 \mu \mathrm{g} / \mu \mathrm{l}$ in water containing $0.5 \%$ Fast Green. DNA was injected subretinally in E18 rat eyes and electroporated with five pulses $(50 \mathrm{~V}, 50 \mathrm{~ms})$. Electroporated retinas were dissected out immediately and cultured as explants for $24 \mathrm{~h}$ and processed for immunostaining as described above.

Time-lapse microscopy and quantification. For time-lapse videomicroscopy, postnatal day $0(\mathrm{P} 0)$ retinal explants were infected with a GFP or a Numb::Venus retroviral vector and, 24-36 h later, fluorescence was imaged every $10 \mathrm{~min}$ for a period of up to $72 \mathrm{~h}$, as we previously described (Cayouette and Raff, 2003). For quantification, daughter-cell fluorescence was assessed at either the first, second, or third frame (10-30 min) of late anaphase/telophase, depending on which frame both daughters were clearly in focus. Area was manually drawn around the cells and mean fluorescence intensity was calculated using Volocity software (PerkinElmer). Background correction was applied by subtracting mean fluorescence from an adjacent region lacking cells or processes. Percentage difference in fluorescence between daughter cells was calculated from the sum of the mean corrected fluorescence of the two daughters.

\section{Results}

\section{Numb function is required for normal retinal development in vivo}

To uncover the function of Numb and Numblike (NbL) in the mouse retina, we first determined their expression pattern by in situ hybridization and immunohistochemistry at early [embryonic day 13 (E13)], intermediate (E17), and late (P0) stages of 
retinal development. We found that mRNA and protein for both Numb and NbL are expressed in the progenitor as well as in the neuronal layers throughout retinal development (data not shown), suggesting a role during both proliferation and differentiation phases.

To determine numb/nbl function in mouse retinal development in vivo, we conditionally inactivated both numb and $n b l$ in RPCs using the Cre/loxP system. To do this, we crossed the Numb/NbL floxed mouse (Wilson et al., 2007) with the $\alpha$-Cre transgenic line, which expresses Cre recombinase and a GFP reporter under the regulation of the $\alpha$ enhancer of Pax6. The $\alpha$ enhancer is active in RPCs of the temporal and nasal regions of the peripheral retina starting from $\sim$ E10.5 (Marquardt et al., 2001). The resulting conditional double knock-out embryos (cDKOs; $\alpha$-Cre; $n u m b^{\text {flox/flox }} ; n b l^{\text {flox/flox }}$ ) were analyzed and numb heterozygotes were used as controls (control; $\alpha$-Cre; $\left.n u m b^{+/ \text {flox }} ; n b^{\text {flox/flox }}\right)$. As expected, immunostaining with an antibody that recognizes both Numb and $\mathrm{NbL}$ on E13.5 cDKO retinal sections demonstrated a major loss of signal in the peripheral retina, indicating efficient gene inactivation of $N u m b$ and $N b L$ and confirming the specificity of the antibody (Fig. 1A,B). Since NbL can compensate for loss of Numb function (Zhong et al., 2000), all the experiments presented below were done on cDKO. For simplicity, we will refer only to Numb in the remainder of the text.

By P15, a stage when all retinal cell types have been generated and the retinal layers are clearly defined, the eyes of cDKO animals were approximately half the size of those of controls (Fig. $1 C)$. Consistent with a previously reported function of Numb in cadherin-based adhesion of radial glial cells (Rasin et al., 2007), we found that the retina of P15 cDKO animals is severely disorganized (Fig. 1D,E). Immunostainings for cell-type-specific markers showed that all major classes of cells are decreased in the cDKO (Fig. $1 F-S$ ). These results show that early inactivation of Numb leads to a decreased number of all major retinal cell types, suggesting that Numb might generally promote the maintenance of the progenitor pool, cell survival, or a combination of both.

\section{Numb promotes cell-cycle progression at early stages of retinogenesis}

To understand how Numb inactivation leads to the dramatic hypoplasia observed in the adult retina, we analyzed cDKO retinas at E13.5, a stage when the first retinal neurons are generated. We found that the peripheral retina of E13.5 cDKO mice is already thinner than that of controls and contains fewer cells labeled for the proliferation marker Ki-67 and the mitotic cell marker PH3 (Fig. 2A-F). The number of horizontal and retinal ganglion cells (RGCs), the two main neuronal cell types produced at this stage, is also reduced (Fig. $2 G-L$ ), and the E10.5 retina does not show staining for RGC and horizontal cell markers (data not shown), excluding the possibility that precocious neuronal differentiation is responsible for the reduced RPC pool size.

We then considered that increased cell death might explain the reduced number of RPCs and neurons observed at E13.5, but staining for activated caspase-3 at E11.5 and E13.5 revealed no significant changes in cell death (E13.5: control, $2.4 \pm 1.3$ cells/ $200 \mu \mathrm{m}, n=4$; cDKO, $3.2 \pm 1.1$ cells $/ 200 \mu \mathrm{m}, n=4)$. At E16.5 and P0, however, we found an important increase in the number of caspase-positive cells in cDKO compared with controls (data not shown). Intriguingly, we noticed that the timing of appearance of dead cells in cDKO correlates with the appearance of a dysmorphic retinal neuroepithelium. At E13.5, the cDKO retinas are normally layered and display the expected apical staining of the polarity proteins Par-3 and atypical PKC (data not shown). In addition, there are no ectopic RPC mitoses at E13.5. As seen with PH3 staining, all mitoses appear at the apical surface (Fig. 2D,E). Since the increased cell death and disrupted neuroepithelium polarity are observed after the initial reduction of RPC and neuronal cell numbers, we excluded these phenotypes as potential explanations for the hypocellularity observed in CDKOs at E13.5, although they most likely contribute to the reduced cell number observed in the adult $\mathrm{cDKO}$ retina.

A possible explanation for the reduced RPC pool size and decreased neurogenesis observed in $\mathrm{CDKO}$ retinas at E13.5 was that Numb might be required to instruct self-renewing asymmetric cell divisions ( $\mathrm{P} / \mathrm{D}$ divisions), as proposed in cortical progenitors (Petersen et al., 2002, 2004; Li et al., 2003). To study Numb function in the regulation of symmetric and asymmetric divisions in the intact retinal neuroepithelium, we used retroviral vectors to introduce Cre recombinase into individual RPCs in retinal explants. With this approach, Numb is clonally inactivated and the impact on the mode of cell division can be easily studied. We infected E13.5 retinal explants prepared from $\mathrm{Numb} / \mathrm{NbL}$ floxed mice with the Cre-expressing retroviral vector, and cultured the explants for $2 \mathrm{~d}$, a period long enough for the infected RPCs to undergo one to two rounds of division. The explants were then sectioned and stained for the proliferation marker Ki-67. Using expression of GFP to identify the infected cells, we focused our attention on the two-cell clones. As expected, RPCs divided to generate three different combinations of daughter-cell pairs (Fig. 3A): (1) two Ki-67-positive cells [proliferative divisions that give rise to two progenitors ( $\mathrm{P} / \mathrm{P}$ divisions) ] (2) one Ki67-positive cell and one Ki-67-negative cell [selfrenewing divisions that give rise to a progenitor and a differentiating cell (P/D divisions)]; and (3) two Ki-67-negative cells [terminal divisions that give rise to two differentiating cells $(\mathrm{D} / \mathrm{D}$ divisions)]. Surprisingly, we did not find any difference in the proportion of clones containing each of the three different daughter-cell combinations upon Cre expression (Fig. 3B), indicating that Numb is not required for the production of selfrenewing (P/D) asymmetric cell divisions in E13.5 RPCs. Nonetheless, clonal inactivation of Numb did have an effect on proliferation, as we observed an increase in the proportion of one-cell clones at the expense of two-cell clones in the Creinfected explants (Fig. 3C), consistent with the reduced number of RPCs observed in cDKO mice in vivo. These one-cell knockout clones are composed of the same proportion of RPCs and differentiating cells as controls $(53 \pm 4 \%$ RPCs and $47 \pm 4 \%$ differentiating cells in Cre-infected clones, compared with $57 \pm$ $3 \%$ RPCs and $43 \pm 3 \%$ differentiating cells in control clones), further suggesting that Numb inactivation does not affect the mode of RPC division.

Since the reduced RPC pool is not caused by increased cell death, precocious neuronal differentiation, or defects in selfrenewing $\mathrm{P} / \mathrm{D}$ divisions, we suspected that Numb function might be required for normal cell-cycle progression in early RPCs. To test this possibility, we injected BrdU at E12.5 in cDKO and control mice, and $18 \mathrm{~h}$ later we collected the eyes and stained for $\mathrm{BrdU}$ and the proliferation marker Ki67. In this experiment, cells that exited the cell cycle after injection of BrdU should be BrdUpositive and Ki67-negative, whereas the cells that are still cycling should be both BrdU-positive and Ki67-positive (Fig. 3D). Surprisingly, we found that the proportion of cells exiting the cell cycle is reduced in cDKO compared with controls (Fig. 3E). Since both the number of RPCs and neurons is decreased at this stage in cDKOs, these results strongly suggest that cDKO RPCs are arrested in the cell cycle or cycling at a slower rate. Flow cytometry 

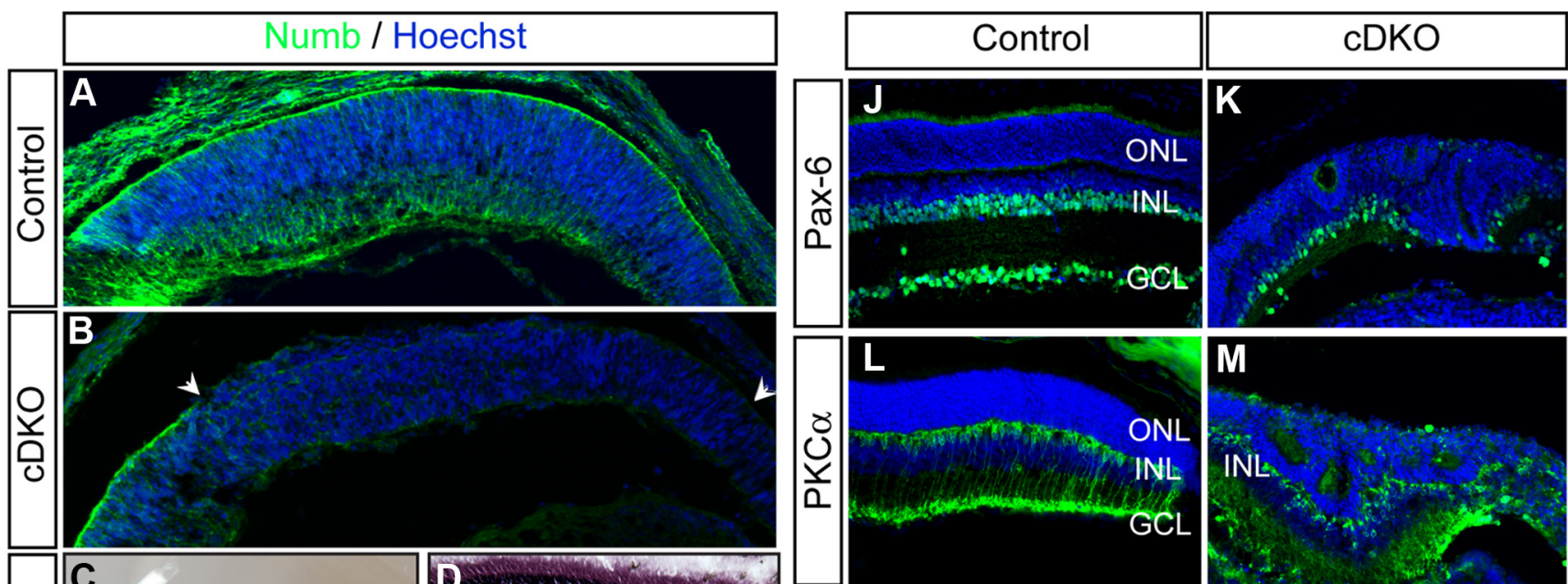
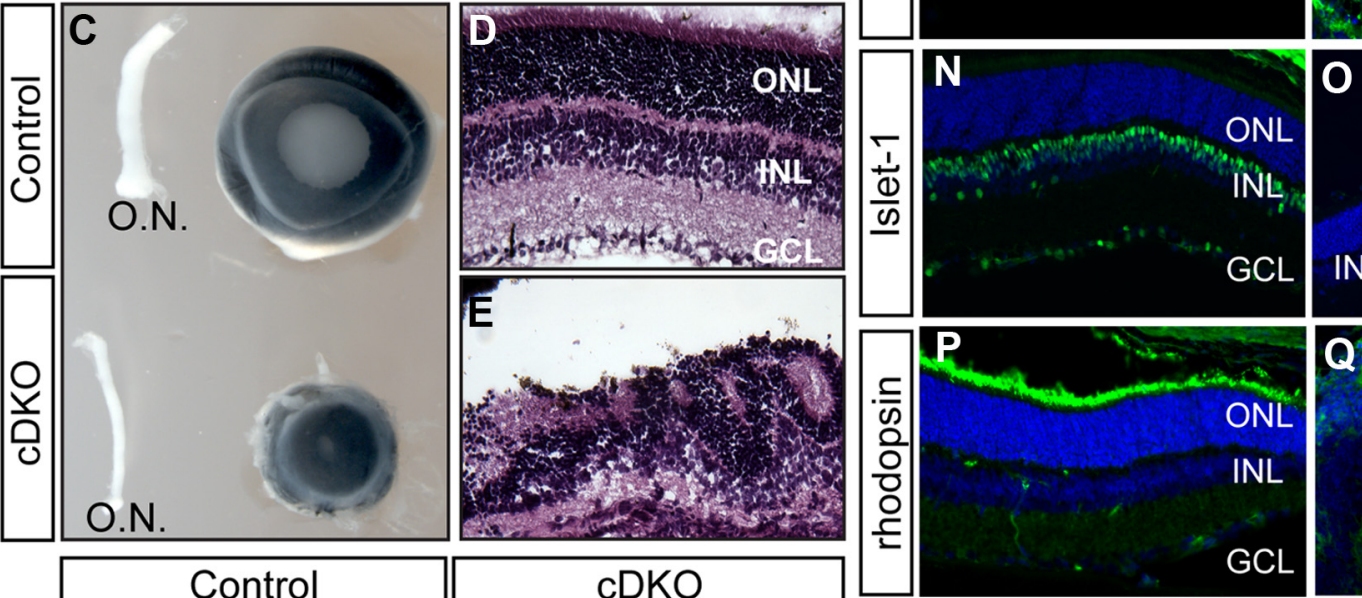

INL
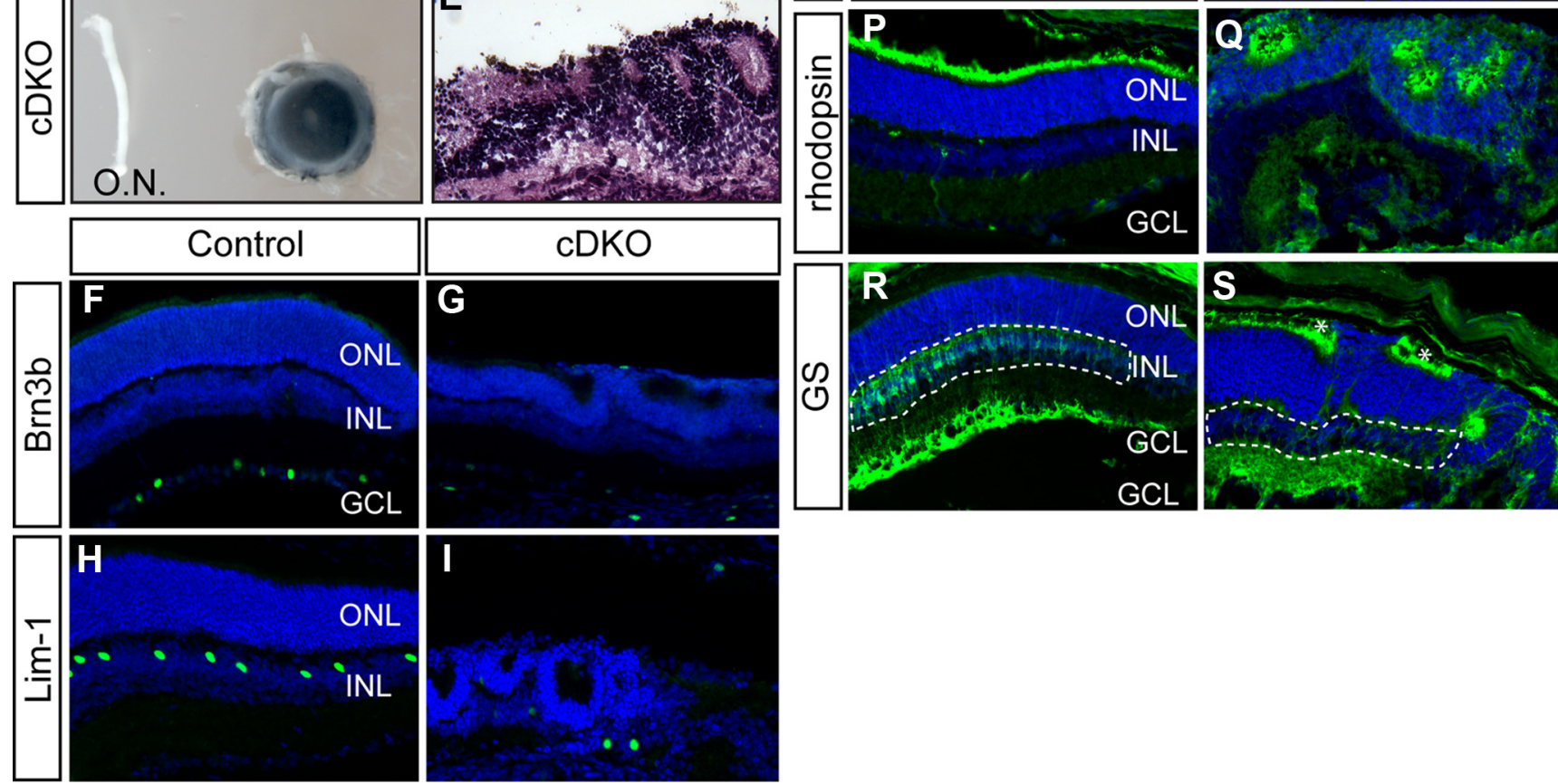

Figure 1. Conditional Numb/NbL inactivation in the retina disrupts neuroepithelial integrity and decreases cell production. $\boldsymbol{A}, \boldsymbol{B}$, E16.5 retinal sections of the Cre-positive region of control ( $\boldsymbol{A}$;

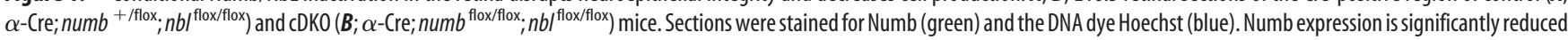
in the peripheral retina of the CDKO (between arrowheads) compared with controls. C, Micrographs of P15 eyes and optic nerves (0.N.) from control and cDKO littermates. D, E, P15 retinal sections of the Cre-positive region from control and CDKO mice stained with hematoxylin and eosin. F-S, P14 retinal sections of the Cre-positive region from control and cDKO mice stained for different cell-type-specific markers. The number of cells expressing markers of RGCs (Brn3b and Pax-6), horizontal cells (Lim-1), amacrine cells (Pax-6), bipolar cells (PKC and Islet1), rod photoreceptors (rhodopsin) and Müller cells (GS, glutamine synthetase) is reduced in CDKO. Dashed line in $\boldsymbol{R}$ and $\boldsymbol{S}$ encloses the inner nuclear layer (INL), where Müller cell bodies are located. Some nonspecific GS staining is seen in the CDKO retina (S, asterisks). All sections were counterstained with Hoechst (blue). GCL, ganglion cell layer; ONL, outer nuclear layer; INL, inner nuclear layer.

analysis, however, revealed no changes in the proportion of cells at different phases of the cell cycle (Fig. 3F), whereas we found a $50 \%$ increase in cell-cycle time in the cDKO RPCs at E13.5 (Fig. $3 G)$. Together, these results indicate that Numb maintains the progenitor pool in the developing retina, but does so independently of an effect on self-renewing asymmetric divisions. Instead, Numb favors normal cell-cycle progression, and an elongated RPC cycle appears responsible for the reduced number of neurons and progenitors in $\mathrm{CDKOs}$ at this stage.

Numb is required cell-autonomously to promote terminal asymmetric cell divisions

Although the slower RPC cycle at early stages of retinogenesis can account for the retinal hypoplasia observed in adult cDKO mice, 


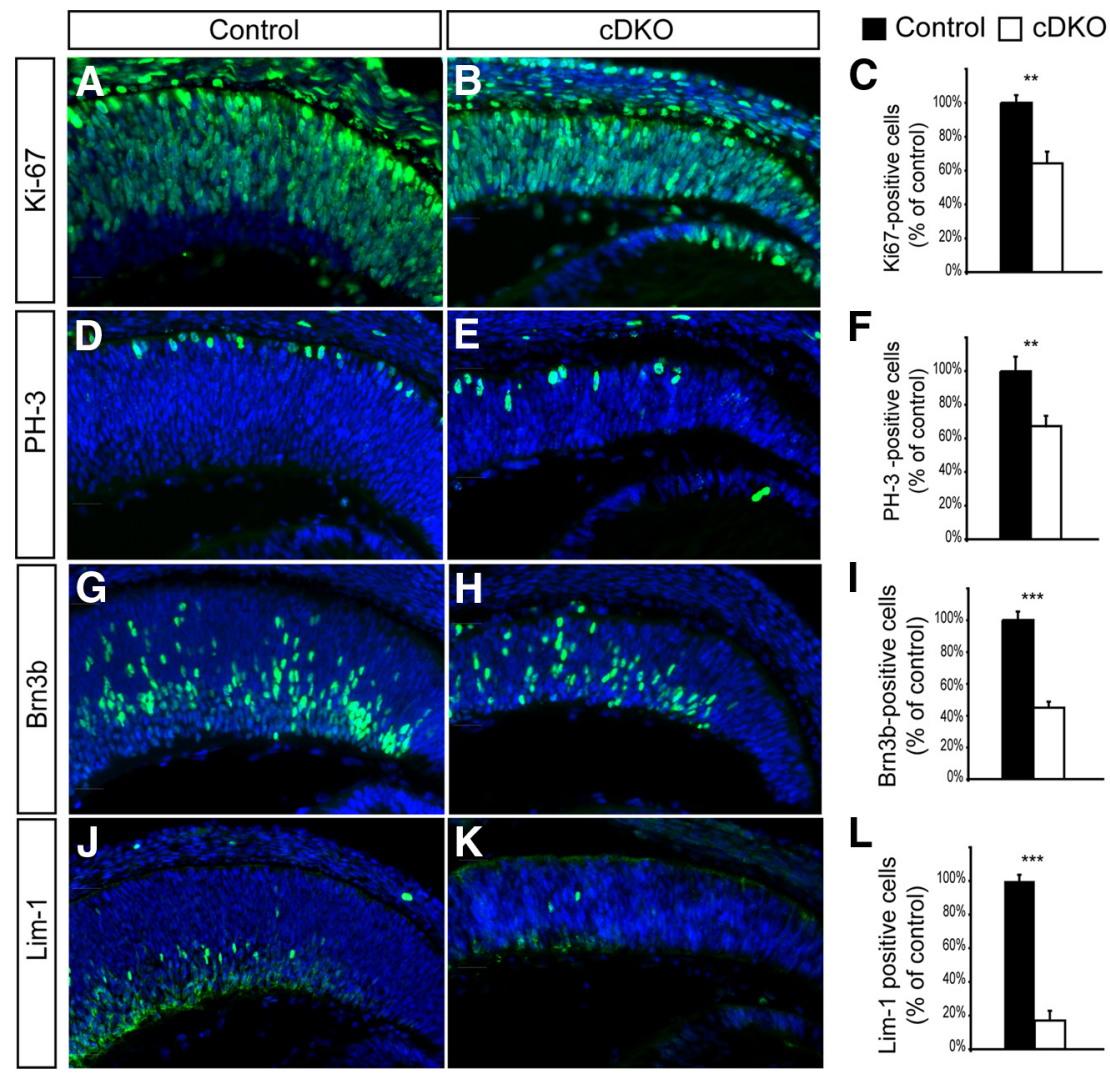

Figure 2. Conditional Numb/NbL inactivation in the retina reduces progenitor cell number but does not cause precocious neuronal differentiation. $\boldsymbol{A}-\boldsymbol{F}, \mathrm{E} 13.5$ retinal sections of the Cre-positive region from control and $\mathrm{CDKO}$ mice stained for the proliferation marker Ki-67 $(\boldsymbol{A}, \boldsymbol{B})$ and the mitotic cell marker $\mathrm{PH}-3(\boldsymbol{D}, \boldsymbol{E})$. The number of cells for both markers is significantly decreased in the CDKO ( $\boldsymbol{C}, \boldsymbol{F}$; mean $\pm \mathrm{SEM}, n=4 ;{ }^{* *} p=0.005$; Student's $t$ test). $\boldsymbol{G}-L$, E13.5 retinal sections of the (re-positive region from control and CDKO mice stained for the RGC marker Brn3b $(\boldsymbol{G}, \boldsymbol{H})$ and the horizontal cell marker Lim- $1(\boldsymbol{J}, \boldsymbol{K})$. Quantifications of the number of marker-positive cells are shown in $I$ and $L\left(n=4\right.$, mean $\pm S E M,{ }^{* * *} p=0.001$, Student's $t$ test).

Numb might also have other functions at late stages of retinogenesis that could contribute to the adult phenotype, such as regulating terminal asymmetric cell divisions $\left(\mathrm{D}_{\mathrm{x}} / \mathrm{D}_{\mathrm{y}}\right)$. Since the cDKO mice could not be used to address this question due to the severe early proliferation defects and later cell death, we used the PLAP or PLAP-Cre retroviral vectors to clonally inactivate Numb in RPCs from P0 by infecting retinal explants prepared from Numb/NbL floxed mice. Surprisingly, we found that the size of the clones produced $17 \mathrm{~d}$ after inactivation of Numb in P0 RPCs is not different from that of controls (Fig. $4 A, B$ ), indicating that, in contrast to early loss of Numb, late inactivation does not affect cell death or proliferation. Although we found no change in clone size, what was immediately apparent was that the composition of the Numb knock-out clones is markedly different, containing fewer amacrine, bipolar, and Müller cells (Fig. 4A,C).

It appeared unlikely that Numb could regulate all the signaling pathways involved in the production of these three different cell types. Instead, since most mixed two-cell clones produced by P0 RPCs are composed of one photoreceptor and either an amacrine, bipolar, or Müller cell (Turner and Cepko, 1987), we hypothesized that Numb inactivation might render RPCs unable to generate such divisions. To test this hypothesis, we focused our analysis on the two-cell clones, which were generated by RPCs undergoing a terminal division. Remarkably, we found that asymmetric terminal divisions $\left(D_{x} / D_{y}\right)$ are drastically reduced upon Numb inactivation, while symmetric terminal divisions $\left(D_{x} / D_{x}\right)$ are increased (Fig. $\left.4 D\right)$. More specifically, asym- metric terminal divisions that give rise to a photoreceptor and another cell type (amacrine, bipolar, or Müller cell) are reduced, whereas symmetric terminal divisions that give rise to two photoreceptor cells are increased (Fig. 4E). Symmetric terminal divisions that give rise to two amacrines, bipolars, or Müller cells are very rare, even in controls, and were not increased in CDKO (data not shown). Together, these results demonstrate that Numb function is essential for the production of terminal asymmetric cell divisions producing a photoreceptor and an amacrine, bipolar, or Müller cell in the postnatal mouse retina.

\section{Numb gain-of-function inhibits the production of terminal asymmetric cell divisions}

Since inactivation of Numb in late RPCs increased symmetric terminal divisions generating two photoreceptors at the expense of asymmetric terminal divisions, we postulated that Numb might function to inhibit the photoreceptor fate. If this were the case, we expected that Numb gain-of-function in P0 RPCs would decrease photoreceptor production and favor nonphotoreceptor cell fates. To test this prediction, we overexpressed Numb in P0 RPCs using retroviral vectors and analyzed the two-cell clones 14 d later. Surprisingly, Numb gain-offunction, similar to Numb loss-of-function, results in a decrease of asymmetric terminal divisions generating a photoreceptor and another cell type, and an increase of symmetric terminal divisions generating two photoreceptors (Fig. $4 F$ ). These results indicate that Numb does not specifically inhibit the photoreceptor fate.

\section{Numb is asymmetrically inherited in a subset of terminal divisions}

How could Numb regulate asymmetric outcomes in terminal divisions? One possibility is that, in some divisions, Numb is asymmetrically inherited by the daughter cells, inducing them to adopt distinct fates. If so, then both genetic depletion and overexpression would tend to promote symmetric outcomes. To test for the asymmetric segregation of Numb, we first used a Numb antibody (Fig. $1 A, B)$. As we previously reported (Cayouette et al., 2001; Cayouette and Raff, 2003), Numb labeling appears enriched on the apical side of mitotic RPCs (Fig. 5A). Detailed 3D confocal imaging and colabeling with the junction marker $\mathrm{ZO}-1$, however, revealed that Numb is not found in the apical membrane per se, but localizes mostly basolateral with a distinctive enrichment in the subapical junctional complex, which sometimes looks like a continuous crescent, depending on the $z$ level at which it is observed (Fig. $5 B-J$ ). In a recent study, it was proposed that the junctional enrichment of Numb is not maintained when cells round up for mitosis, and that interphase cell processes wrapping around mitotic profiles might give the false impression of an apical crescent (Rasin et al., 2007). To determine whether interphase cell processes could confuse our interpretation, we expressed a membrane-tagged GFP (f-GFP) in RPCs and stained 

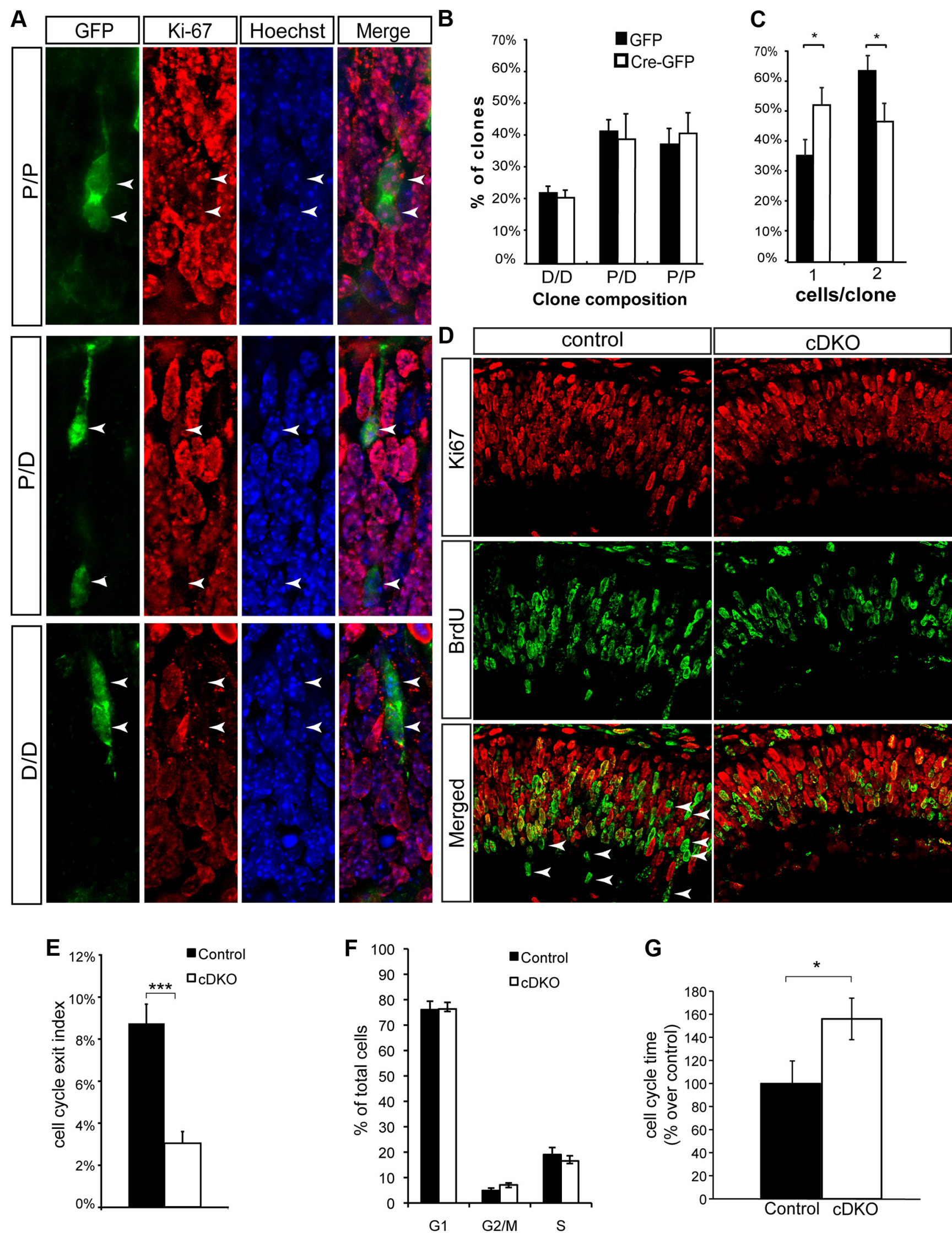

Figure 3. Inactivation of Numb/NbL in early RPCs does not affect the mode of cell division but slows down cell-cycle progression. $A$, Examples of two-cell clones obtained $2 \mathrm{~d}$ after infection of E13.5 numb $b^{\text {flox/flox; }} n b^{\text {flox/flox }}$ retinal explants with a GFP-Cre retroviral vector (green). The sections were stained for the progenitor cell marker Ki-67 (red) and counterstained with Hoechst (blue). Examples of the three different combinations of daughter cell pairs obtained are shown: two Ki-67-positive cells (top, P/P), one Ki67-positive cell and one Ki-67-negative cell (middle, P/D), and two Ki-67-negative cells (bottom, D/D). B, C, Quantitative analysis of daughter-cell combinations in two-cell clones $(\boldsymbol{B})$, and average number of cells per (Figure legend continues.) 
A

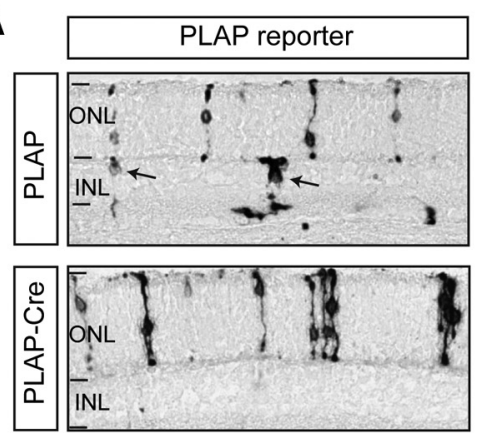

B

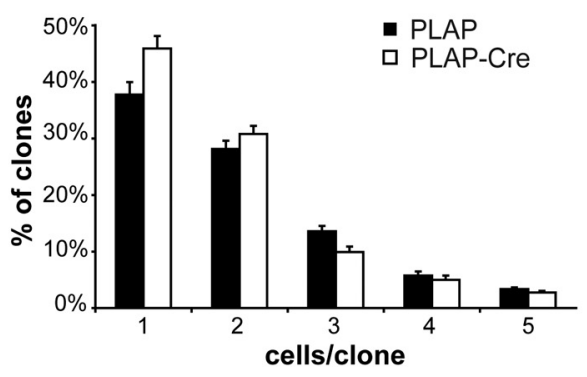

C

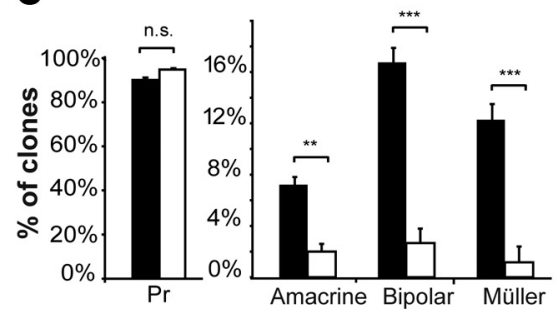

E

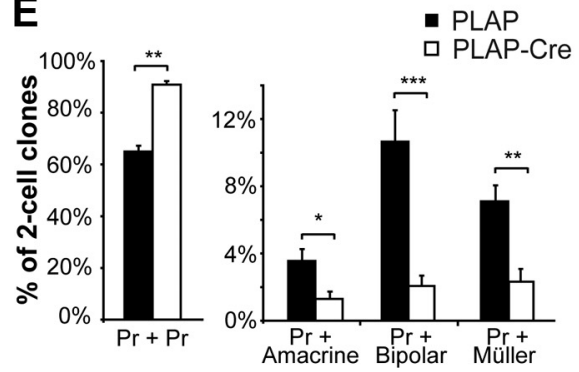

D

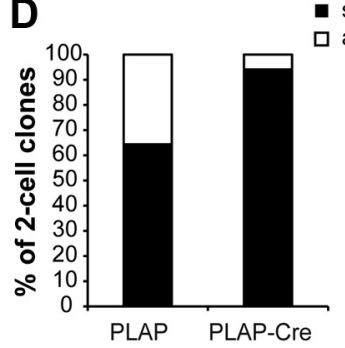

$\mathbf{F}$

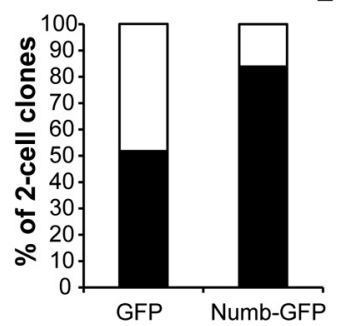

Figure 4. Clonal inactivation of Numb/NbL in late RPCs decreases terminal asymmetric cell divisions. $A$, Example of clones obtained $17 \mathrm{~d}$ after infection of numb $b^{\text {flox/flox; }},\left.n b\right|^{\text {flox/flox }}$ retinal explants at $\mathrm{PO}$ with a control retroviral vector expressing PLAP only (PLAP) or PLAP and Cre recombinase (PLAP-Cre) to inactivate Numb/NbL. Control clones contain both photoreceptors located in the outer nuclear layer (ONL) and various cells in the inner nuclear layer (INL; arrows), whereas knock-out clones contain almost exclusively photoreceptors. $\boldsymbol{B}$, Average number of cells per clone. $\boldsymbol{C}$, Proportion of clones containing at least one of the four major retinal cell types produced postnatally. Results in $\boldsymbol{B}$ and Care shown as mean \pm SEM, $n=6$; a total of $>1500$ clones were analyzed for each condition. $\boldsymbol{D}$, Proportion of symmetric and asymmetric terminal divisions in control and Numb/NbL knock-out RPCs. $\boldsymbol{E}$, The specific composition of the two-cell clones from the experiment shown in $\boldsymbol{D}$. Numb/NbL inactivation in late RPCs specifically reduces asymmetric cell divisions that produce a photoreceptor and an amacrine, bipolar, or Müller cell, and increases symmetric divisions that produce two photoreceptors (Pr). Mean \pm SEM, PLAP: $n=367$ two-cell clones; PLAP-Cre: 467 two-cell clones, ${ }^{*} p=$ $0.01-0.05,{ }^{* *} p=0.001-0.005,{ }^{* * *} p=0.001$, Student's $t$ test. $\boldsymbol{F}$, Proportion of symmetric and asymmetric terminal divisions $10 \mathrm{~d}$ after overexpression of GFP ( $n=7 ; 567$ clones analyzed) or Numb (Numb-GFP; $n=5 ; 229$ clones analyzed) in PO RPCS.

for Numb. While Numb labeling in interphase cell processes is indeed detected around mitotic cells, these processes could be easily distinguished from the mitotic cell membranes. Also, clear colabeling of Numb and f-GFP was observed in mitotic cells, including an enrichment in the adherens junctions and a gap at the apical membrane (Fig. $5 K-P$ ). To visualize Numb expression

(Figure legend continued.) clone (C). Bars show mean \pm SEM ( $n=3$ animals; 250 clones per condition were analyzed; ${ }^{*} p=0.01-0.05$; Student's $t$ test). $\boldsymbol{D}$, Cell-cycle exit analysis in the control and CDKO retina. Eighteen hours after a single injection of BrdU at E12.5, retinal sections were stained for Ki67 (red) and BrdU (green). Arrowheads point at BrdU-positive and Ki67negative cells. $\boldsymbol{E}$, Cell-cycle exit index (number of BrdU +/Ki67 - cells divided by total number of BrdU + cells) is reduced in the CDKO retina $\left(n=3\right.$; mean $\pm S E M,{ }^{* * *} p=0.001$, Student's $t$ test). $\boldsymbol{F}$, Flow cytometry analysis of cell cycle in CDKO and control retinas at E13.5 (mean \pm SEM, $n=3$ ). G, Cell-cycle time analysis (see Materials and Methods) in CDKO and control at E13.5 (control, $n=4 ; \mathrm{CDKO}, n=3$; mean $\pm \mathrm{SD},{ }^{*} p=0.01$, Student's t test). The percentages shown represent a cell cycle of $11.4 \mathrm{~h}$ in controls and $17.8 \mathrm{~h}$ in cDKO. more precisely in P0 RPCs, we used immunogold electron microscopy. In interphase cells, Numb is not detected at the apical membrane, but is enriched at the adherens junctions (Fig. 5Q), in agreement with our immunofluorescence results and a previous report in radial glia (Rasin et al., 2007). In mitotic cells, Numb signal is detected and appears more abundant on the apical-most side of the cell (Fig. $5 R-V$ ). These results indicate that Numb is enriched asymmetrically in mitotic RPCs, suggesting that it might be partitioned unequally between daughter cells.

We next asked whether some RPC divisions might give rise to daughter cells with differential levels of Numb. To do this, we expressed a fluorescently tagged Numb reporter protein (Numb::Venus) in RPCs growing in dissociated or explant cultures using a retroviral vector. First, we verified that Numb::Venus actually reflects the localization of endogenous Numb by comparing its distribution to the signal obtained by immunostaining. In interphase RPCs, Numb::Venus shows a vesicular pattern in the cytosol and near the membrane, which is very similar to the endogenous staining pattern (Fig. $6 A-C$ ) and consistent with the known role of Numb in endocytosis. In mitotic RPCs, Numb::Venus is mostly membrane associated and localized around most of the basolateral cell cortex, with an enrichment toward the apical side, most likely representing the adherens junctions (Fig. $6 D)$. These results are consistent with our immunostaining data and suggest that Numb::Venus reflects the endogenous Numb expression pattern. Since asymmetric inheritance of Numb is readily observed by immunostaining in dissociated cultures (Cayouette et al., 2001), we first analyzed dissociated RPCs expressing Numb::Venus by time-lapse microscopy. As shown in Figure 6E, we found that the localization of Numb::Venus is highly dynamic in RPCs. Numb::Venus is mostly vesicular and membrane associated during interphase but, in some cells rounding up for mitosis, it is rapidly redistributed to the membrane and forms a crescent that is asymmetrically inherited by one of the daughter cells (Fig. $6 E$ ).

To investigate whether Numb is asymmetrically inherited by the daughter cells of RPCs in the intact retinal neuroepithelium, we infected $\mathrm{P} 0$ retinal explants with the Numb::Venus vector, or with a control vector expressing GFP only, and imaged RPCs by time-lapse microscopy. The relative fluorescence intensity in each daughter cell of RPC divisions was then quantified in telophase/late telophase (see Materials and Methods). Interestingly, while we found that most divisions distribute the Numb::Venus signal symmetrically (Fig. $6 F$ ), other divisions show clear asymmetric Numb::Venus signal in the daughter cells (Fig. 6G). More than $10 \%$ of RPC divisions generate daughter cells that have a 

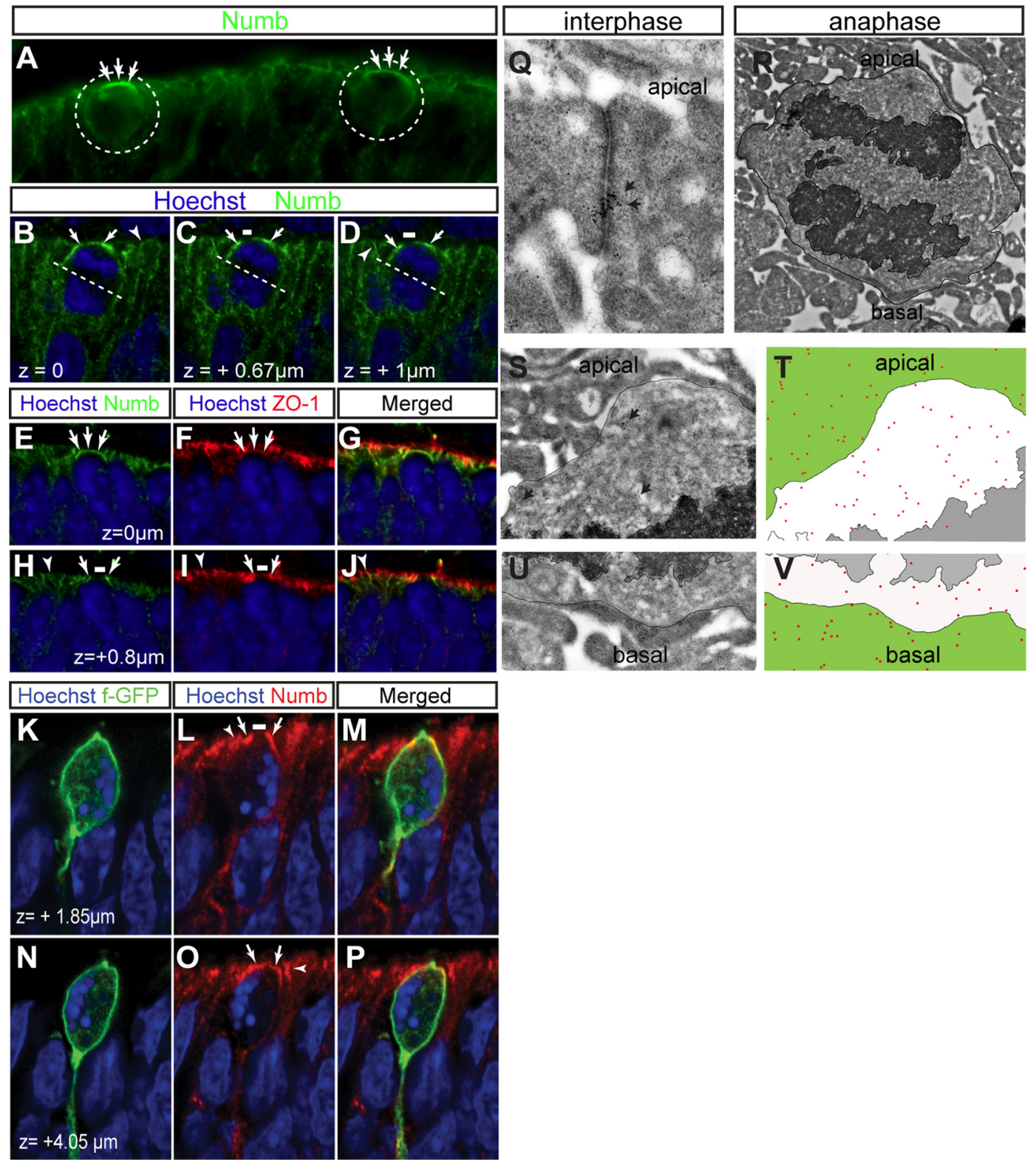

Figure 5. Numb localizes to the subapical junctional complex in RPCS. $\boldsymbol{A}$, Numb staining (green) shows apical crescent-like expression (arrows) in mitotic cells (dotted circles). $\boldsymbol{B}-\boldsymbol{D}$, Confocal $Z$-stack images of a PO mouse retinal section stained for Numb (green), showing an RPC undergoing mitosis at the apical surface. In interphase RPCs, Numb is enriched in the apical end-feet (arrowheads). In mitotic RPCs, Numb is seen around the basolateral membrane, but is enriched toward the apical side, where it forms a crescent that appears smooth and continuous at certain $z$ levels ( $\boldsymbol{B}$, arrows), but contains a distinctive unlabeled gap at others ( $\boldsymbol{C}, \boldsymbol{D}$, white line). The dotted line indicates the plane of division. $\boldsymbol{E}$-J, Confocal $z$-stack images of P0 retinal sections showing a mitotic cell costained for Numb (green) and the tight junction marker zona occludens-1 (Z0-1) (red). Numb staining forms a continuous apical crescent at some z planes (E), but displays an unlabeled gap at others ( $\boldsymbol{H}$, white line). At all $z$ planes, Numb colocalizes with Z0-1 in both interphase ( $\boldsymbol{H}-\boldsymbol{J}$, arrowhead) and mitotic RPCs ( $\boldsymbol{E}-\boldsymbol{J}$, arrows), but is excluded from the presumptive apical membrane ( $\boldsymbol{H}-\boldsymbol{J}$, white line). $\boldsymbol{K}-\boldsymbol{P}$, Confocal $\boldsymbol{Z}$-stack images of E18 retinal explant electroporated with f-GFP (green) and stained for Numb (red) $24 \mathrm{~h}$ later. Apical enrichment of Numb (arrows) colocalized with f-GFP at the plasma membrane of mitotic RPCs. Different $z$ planes are shown, as labeled. Arrows point to Numb staining that colocalizes with f-GFP. Arrowheads point to Numb staining in interphase cells that does not colocalize with f-GFP. Q-V, Immunogold electron microscopy for Numb in the P0 mouse retina. In interphase cells (Q), Numb is concentrated at the junctions, which are easily identified by their electron-dense appearance. In mitotic cells $(\boldsymbol{R}-\boldsymbol{\eta})$, Numb signal is observed both on the apical and basal side of the cell, but more gold particles were detected on the apical side, as seen in the higher-magnification images $(\boldsymbol{S}, \boldsymbol{U})$. $\boldsymbol{T}, \boldsymbol{V}$, Diagram reconstructions are shown for the apical $(\boldsymbol{S})$ and basal $(\boldsymbol{U})$ side of the cell. Gold particles (Numb signal) are shown as red dots, the extracellular space is green, the cytoplasm is white, and the DNA is gray. The depicted cell divides with a mitotic spindle aligned vertically, along the apicobasal axis.

difference in relative fluorescence signal intensity that is $\geq 3 \mathrm{SDs}$ away from the GFP control. Because the control GFP protein was always symmetrically inherited by the progeny, this asymmetric inheritance of Numb::Venus is not simply the result of normal variability in protein distribution between sister cells (Fig. $6 \mathrm{H}, I$ ). These results provide direct evidence that some terminal RPC divisions give rise to daughter cells with differential amounts of $\mathrm{Numb}$ in an intact retinal neuroepithelium, supporting a model in which unequal Numb expression in sibling cells of terminal divisions might drive asymmetric outcomes.

Numb is required to repress Notch signaling in late RPCs

How could different Numb expression in sibling cells of terminal divisions instruct asymmetric fates? Since mammalian Numb was previously reported to antagonize Notch signaling (French et al., 2002; McGill and McGlade, 2003; McGill et al., 2009), we 

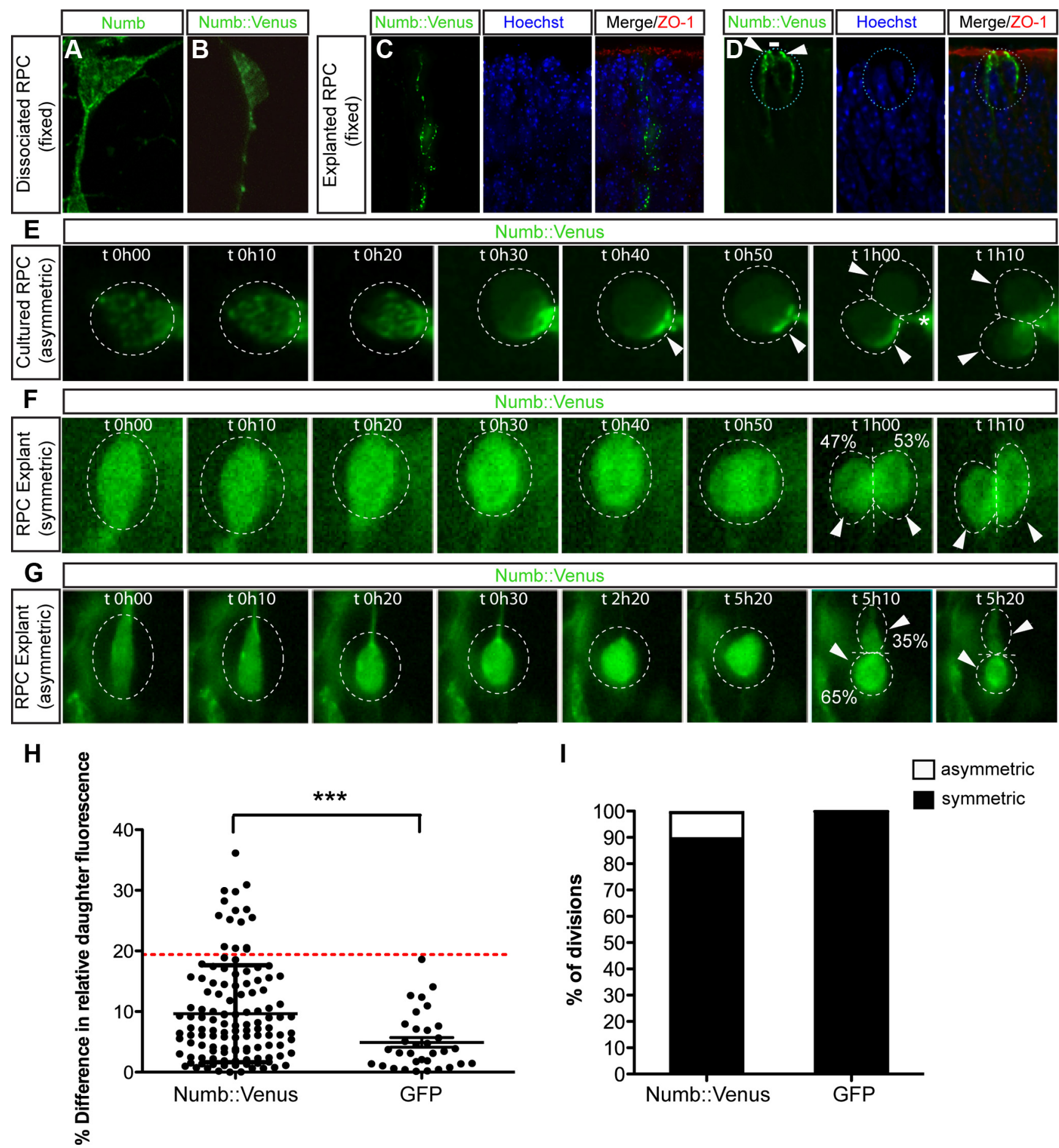

Figure 6. A Numb reporter protein segregates asymmetrically in the daughter cells of RPCs. $A$, An interphase RPC in dissociated culture stained for Numb. Endogenous Numb is mostly vesicular and associated to the membrane. $\boldsymbol{B}, \boldsymbol{C}$, Interphase RPCs expressing the Numb::Venus fusion protein in dissociated culture $(\boldsymbol{B})$ or in retinal explants $(\boldsymbol{C})$ shows a similar expression pattern to endogenous Numb $(\boldsymbol{A}) . \boldsymbol{D}$, In a mitotic RPC, Numb::Venus localizes mostly to the basolateral domain and is excluded from the apical membrane (white line), but is enriched in the subapical domain (arrowheads), and colocalizes with the tight junction marker Z0-1 (red). $\boldsymbol{E}$, Time-lapse sequence of RPCs dividing in dissociated culture. Numb::Venus is mostly cytosolic and punctate in interphase, but relocalizes rapidly to the membrane when the cell rounds up for mitosis, forming a crescent that is asymmetrically inherited by one daughter cell. The process of another cell in the field is also seen touching the dividing cell (asterisk). See supplemental Movie $\mathbf{S 1}$, available at www.jneurosci.org, as supplemental material for the full sequence. This material has not been peer reviewed. $\boldsymbol{F}$, $\mathbf{G}$, Time-lapse sequences of RPCs dividing in P0 retinal explants. Numb::Venus is inherited symmetrically $(\boldsymbol{F})$ and asymmetrically $(\boldsymbol{G})$ by the daughter cells. Percentages shown are the relative fluorescence intensity of each cell in telophase, as used for quantifications. $\boldsymbol{H}$, Relative fluorescence intensity in sibling cells from RPCs dividing in explants. The graph shows the distribution of all cells analyzed in each condition. The red line represents 3 SDs from the mean percentage difference in relative daughter fluorescence of GFP divisions (Numb::Venus, $n=124 ;$ GFP, $n=33 ; * * * p=$ 0.0008, Mann-Whitney U nonparametric test, 2-tailed, 95\% confidence interval). The long line shows the mean and the error bars show the SD. I, Histogram distribution of divisions with a percentage difference in relative daughter fluorescence falling above and below 3 SD from the GFP mean in Numb::Venus and GFP conditions. Divisions with a percentage difference in daughter fluorescence <3 SD from GFP mean were classified as "symmetric," and those above classified as "asymmetric." 
wondered whether Numb might inhibit Notch activity in RPCs, particularly at the stage when they are making asymmetrical terminal divisions. To test this idea, we performed qRT-PCR for Notch target genes on mRNA samples prepared from E14 and P0 retinas. At E14, the expression level of all Notch target genes studied does not change significantly in the $\mathrm{CDKO}$ compared with control retinas, whereas Numb levels are significantly decreased, as expected (Fig. 7A). At P0, however, the expression of Hey-1 is significantly increased in $\mathrm{cDKO}$ retinas compared with controls, while the expression of Hes-1, Hes-5, and Rbpj is not changed (Fig. 7B). Although unlikely, it remained possible that the increased Hey-1 expression observed at $\mathrm{P} 0$ is not contributed from RPCs but from differentiated cells. To exclude this possibility, we performed qRT-PCR on mRNA samples prepared from cells with tetraploid DNA content purified by FACS from P0 peripheral retina. As expected, we found an increase in relative Hey-1 expression in cDKO RPCs compared with controls (control: 2.4 arbitrary units; cDKO: 3.6 arbitrary units), while the expression levels of the other Notch target genes remains unchanged. These results suggest that the lengthening of the cell cycle observed at E14 in cDKO is not caused by alterations of the Notch signaling pathway, and that Numb-mediated repression of the Notch pathway might play a part in the generation of asymmetric terminal divisions produced by $\mathrm{P} 0 \mathrm{RPCs}$.

\section{Notch signaling is required for the production of terminal asymmetric cell divisions}

The above findings suggest that asymmetric inheritance of Numb by one of the sibling cells in terminal divisions might create unequal Notch activity, which could induce each cell to take on a different fate. If this were the case, then blocking Notch activity in both daughters of terminal divisions should promote symmetric at the expense of asymmetric outcomes. To test this prediction, we infected P0 retinal explants with a retroviral vector expressing tMam, a strongly dominant-negative Notch pathway construct (Helms et al., 1999), and analyzed the composition of two-cell clones. Blocking Notch activity virtually abolishes the production of terminal asymmetric divisions giving rise to a photoreceptor and an amacrine, bipolar, or Müller cell, in favor of symmetric terminal divisions producing two photoreceptors (Fig. 7C-E). These results indicate that Notch signaling is required for the production of asymmetric terminal divisions.

In a recent study, it was shown that Notch signaling occurs specifically between sibling cells of radial glia divisions to instruct asymmetric outcomes, rather than through classical lateral inhibition (Dong et al., 2012). To test whether this may be the case in RPC terminal divisions, we plated E19-E20 rat RPCs at clonal density in
E14
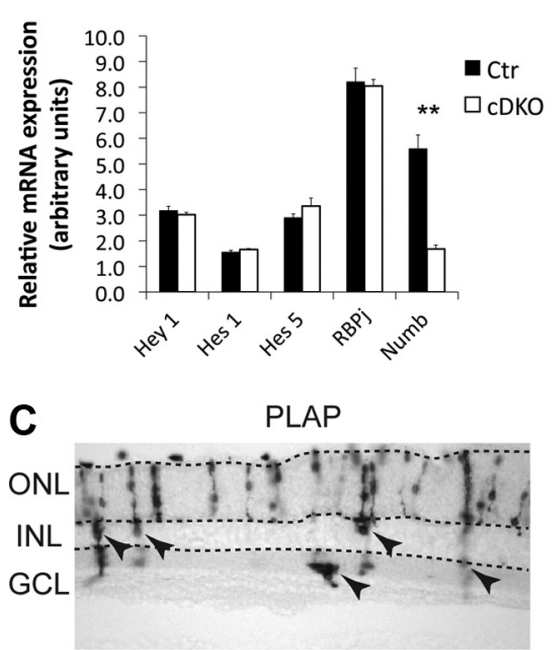

E

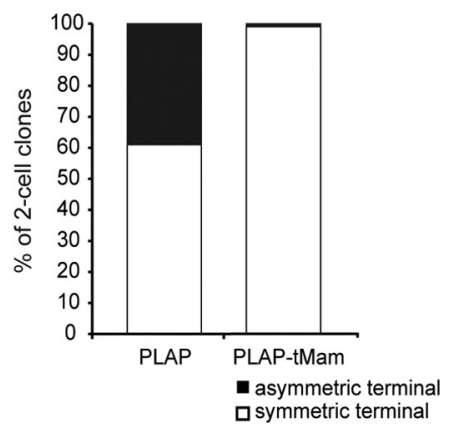

B

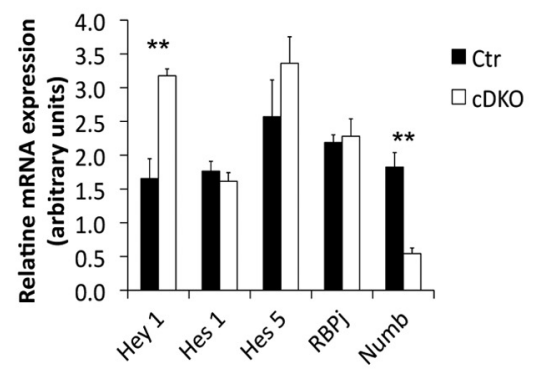

D

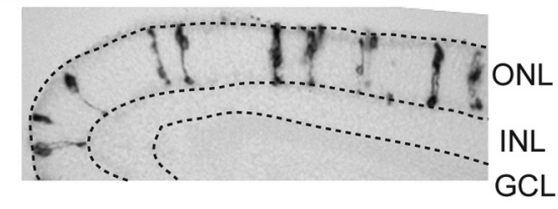

F

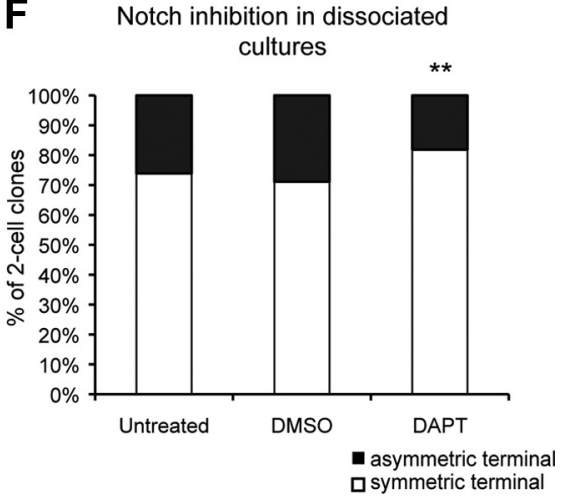

Figure 7. Notch signaling operating between sibling cells is required for terminal asymmetric divisions. $\boldsymbol{A}, \boldsymbol{B}$, Quantitative analysis of Notch target gene expression by qRT-PCR from mRNA samples obtained from E14 $(\boldsymbol{A})$ and P0 $(\boldsymbol{B})$ retinas. Notch target gene expression

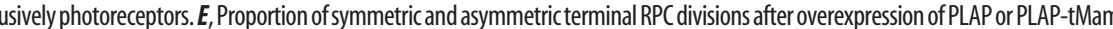
of photoreceptor-containing two-cell clones that are symmetric or asymmetric in clonal-density cultures after inhibition of Notch signaling using DAPT compared with DMSO or untreated controls. Data are from three independent experiments (DAPT, $n=236$; DMSO, $n=210$; untreated, $n=115 ; * * p=0.01, \chi^{2}$ test).

the presence or absence of DAPT, a potent Notch signaling inhibitor, and analyzed the composition of two-cell clones (terminal divisions) $8 \mathrm{~d}$ after plating, as we previously described (Cayouette et al., 2003; Gomes et al., 2011). In this assay, the influence of neighboring cells is eliminated and Notch signaling is limited to sister cells. Interestingly, we found that inhibiting Notch activity in RPCs significantly increases the production of symmetric terminal divisions producing two photoreceptors and decreases asymmetric terminal divisions generating a photoreceptor and another cell type (Fig. 7F). These results suggest that Notch signaling can operate between sibling P0 RPCs to generate terminal asymmetric divisions.

\section{Discussion}

We report here that Numb function changes during retinogenesis, promoting cell-cycle progression at early stages and terminal asymmetric cell divisions at late stages. Since a single allele of 

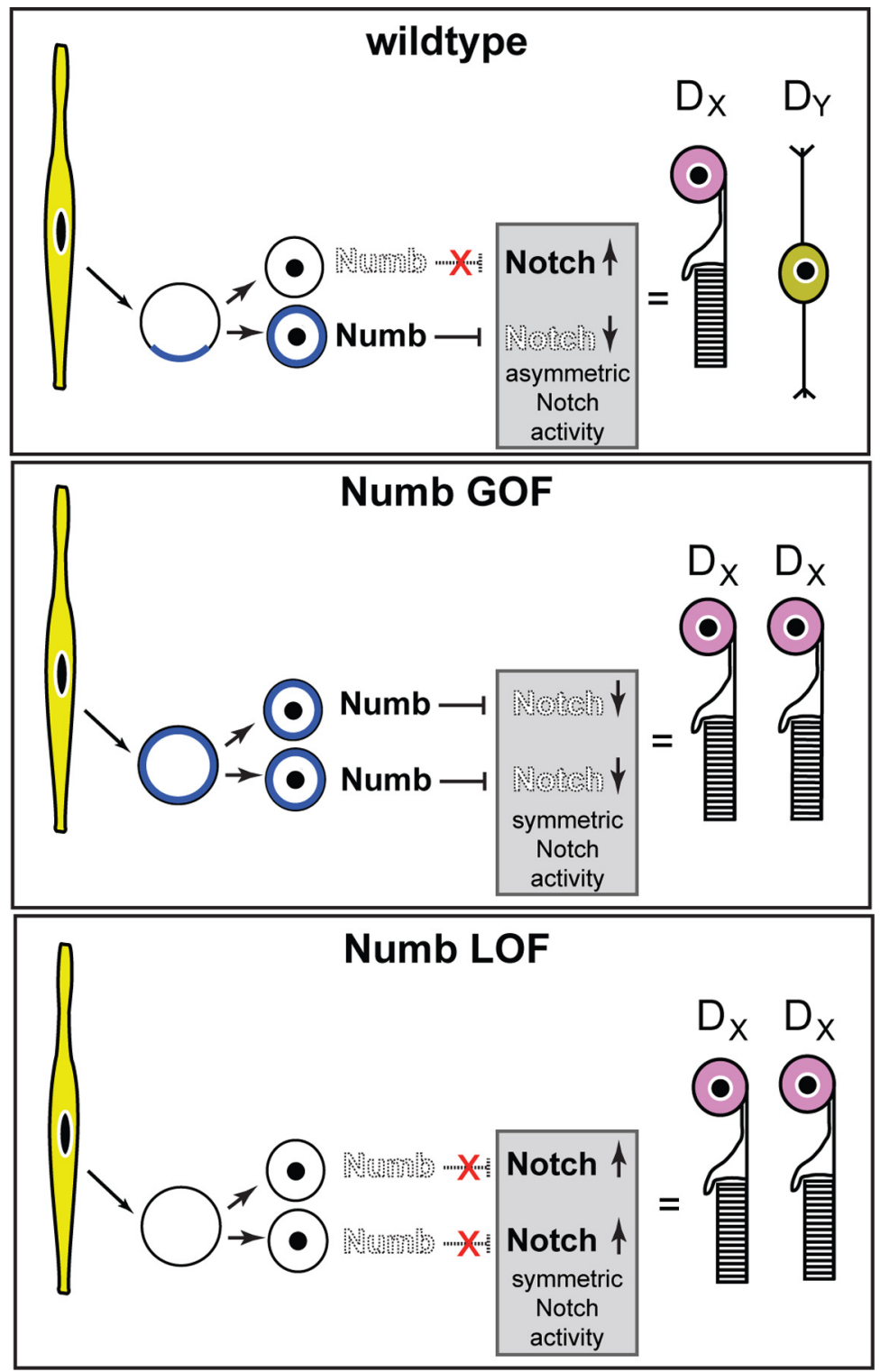

Figure 8. A model for Numb function in terminal asymmetric cell divisions. In wild-type RPCs, some terminal divisions segregate Numb asymmetrically in the daughter cells. Numb represses Notch, creating asymmetric Notch activity between sibling cells, which induces them to adopt distinct fates. In Numb gain-of-function (GOF) or loss-of-function (LOF), an asymmetric Notch activity in the sibling cells cannot be achieved, and both cells take on the same photoreceptor fate.

numb is sufficient to alleviate all retinal phenotypes observed in cDKO in vivo, it is highly unlikely that the different phenotypes observed at different stages of development are due to temporalspecific functions for numb and numblike. We discuss below the implications of these findings and propose a model for Numb function in retinal development.

\section{Numb localization in RPCs}

In agreement with previous studies in mouse and zebrafish neural progenitors (Reugels et al., 2006; Rasin et al., 2007; Alexandre et al., 2010), we report that Numb is not found in the apical membrane of RPCs, but is enriched at the junctional complex and overlaps with the tight junction marker ZO-1. In contrast to a previous report in mouse radial glia (Rasin et al., 2007), however, we find that the subapical enrichment of Numb is maintained in mitosis, at least in some divisions. The reason for the different localization of Numb in mitotic cells in the retina and cortex remains unclear. It may be that Numb localizes asymmetrically in mitotic radial glia but only at specific stages of neurogenesis, or in a small fraction of the cells, making them difficult to find. Alternatively, Numb might be highly dynamic and asymmetrically localized only transiently in mitotic cells. This is supported by our observation that the Numb::Venus fusion protein rapidly moves from a vesicular-like pattern to an asymmetric membrane localization in 10-20 min, and maintains this polarized distribution for no more than 30-40 min. This might make it difficult to catch Numb asymmetry in mitotic cells in fixed samples. Finally, because our results indicate that Numb does not control self-renewing divisions in the retina, whereas it is thought to do so in the cortex, it is possible that Numb localizes differently in mitotic RPCs and cortical radial glia.

With respect to function, the most important issue concerning Numb localization is whether it can be asymmetrically inherited by the daughter cells of some divisions. Asymmetric inheritance of Numb in the daughter cells of neural progenitor divisions was reported in the zebrafish neural tube (Alexandre et al., 2010), but it remained unclear whether this is also the case in mice. Here, we show that a Numb reporter protein is asymmetrically inherited by the daughter cells of $10-20 \%$ of the divisions, depending on whether we define as "asymmetric" the divisions at 2 or 3 SDs away from the GFP control. Interestingly, this figure is similar to the $25 \%$ of asymmetric terminal divisions (2-cell clones) reported in retroviral lineage tracing in the P0 rat retina (Turner and Cepko, 1987), suggesting that asymmetric Numb inheritance might be involved in the production of most asymmetric terminal divisions.

Unfortunately, since the time-lapse movies were not acquired with a confocal microscope, we could not consistently visualize Numb::Venus localization in mitosis relative to the orientation of division. It is therefore not possible at this time to formally demonstrate whether cell division orientation contributes to generating daughter cells with differential amounts of Numb. Nonetheless, circumstantial evidence seems to support this possibility. Numb is enriched asymmetrically toward the apical pole in mitotic RPCs and reorienting the mitotic spindle along the apicobasal axis is likely to increase the chance that Numb segregates asymmetrically in the daughter cells. In addition, we previously showed that RPC division orientation correlates with symmetric and asymmetric outcomes in terminal divisions, and the current study indicates that Numb asymmetry is required for the production of these divisions. It is therefore tempting to speculate that symmetric and asymmetric inheritance of Numb in the daughter cells is regulated by the orientation of the mitotic spindle, especially in light of recent reports showing the importance of cell 
division orientation in the production of asymmetric divisions (Zigman et al., 2005; Postiglione et al., 2011; Das and Storey, 2012), but higher-resolution live imaging will be required to formally prove this point.

\section{Numb function in proliferation}

It remains unclear how exactly Numb regulates cell-cycle progression in the retina, but our data indicate that it is unlikely to involve antagonizing Notch signaling. Indeed, the decreased proliferation observed in the early retina upon Numb inactivation is not consistent with a classical Notch gain-of-function phenotype, and the expression of Notch target genes at E13.5 is unchanged in cDKO. These observations are surprising considering that Numb can act as a tumor suppressor in adult tissue (for review, see Pece et al., 2011), and suggest that Numb has context-dependent functions. Elucidating this issue fell outside the scope of this study, but an interesting possibility is that distinct Numb isoforms might be expressed at specific stages to differentially regulate proliferation and differentiation (Dho et al., 1999; Verdi et al., 1999; BaniYaghoub et al., 2007; Karaczyn et al., 2010).

The proliferation phenotype observed in Numb/NbL cDKO is remarkably similar to that seen in the E2F1-null or E2F1/2/3 triple-null retina, which also have slow-cycling RPCs due to elongation of every phase of the cell cycle (Chen et al., 2009). Whether or not there is a connection between Numb and E2F, or vice versa, remains to be determined but, interestingly, studies in the liver have shown a direct link between E2Fs and Notch signaling (Viatour et al., 2011).

\section{Numb function in terminal asymmetric divisions}

One of the most important and novel findings of our study is that Numb is essential for the production of terminal asymmetric cell divisions in the developing retina. This is similar to Numb function in Drosophila ganglion mother cells or MP2 precursors (Spana et al., 1995; Spana and Doe, 1996; Buescher et al., 1998), where asymmetric inheritance of Numb induces binary neuronal fates at terminal divisions. Interestingly, a recent study showed that Olig2 might act to confer a ganglion mother cell-like phenotype to RPCs and induce them to undergo a terminal division, with the fate of the neuronal daughters depending on the time at which the division takes place (Hafler et al., 2012). We propose here that Numb acts in terminal divisions occurring toward the end of retinogenesis and its unequal inheritance by the daughter cells imposes a bias for asymmetric outcome. The function of Numb in terminal divisions might also be conserved in the developing cortex. Indeed, a fraction of cortical progenitors dividing in culture were shown to segregate Numb asymmetrically in terminal divisions, and asymmetric Numb distribution appears to correlate with different neuronal morphologies (Shen et al., 2002).

Recently, Notch was found to act as an inhibitor of the photoreceptor fate in the developing retina (Jadhav et al., 2006; Yaron et al., 2006). Our finding that inactivation and overexpression of Numb produces the same phenotype, however, is not consistent with a simple model in which Numb instructs the photoreceptor fate by repressing Notch. Instead, our data suggest that Numb does not instruct a specific fate, but acts more generally to specify symmetric or asymmetric outcomes, depending on its relative abundance in sibling cells, as suggested for radial glia (Zhong and Chia, 2008). We propose that symmetric Numb inheritance in the sibling cells leads to equal levels of Notch activity and production of a symmetric photoreceptor/photoreceptor division, whereas asymmetric Numb inheritance leads to unequal levels of
Notch activity and production of an asymmetric photoreceptor/ nonphotoreceptor terminal division (Fig. 8). If this model were correct, one would expect that overexpression of Notch intracellular domain (Notch-ICD) in RPCs should force symmetrical Notch activity between sibling cells and induce photoreceptor/ photoreceptor divisions. A previous study has shown that overexpression of Notch-ICD in RPCs results in the almost exclusive generation of Müller glial cells rather than photoreceptors (Furukawa et al., 2000). It is difficult, however, to compare NotchICD overexpression experiments with our findings because the levels of Notch activation achieved by overexpression are likely much higher than what is observed upon Numb inactivation. In addition, our results indicate that only Hey-1 levels are increased in cDKO RPCs at P0. It is therefore possible that widespread Notch pathway activation leads to Müller cell production, whereas lower or more-specific activation of $\mathrm{Hey}-1$ regulates symmetric versus asymmetric fate outcomes. The different effects of Notch-ICD overexpression and Numb inactivation experiments may also be complicated by the fact that the effect of Numb on Notch activity is different in interphase versus mitotic cells because of interaction with a golgi-associated protein (Zhou et al., 2007). Nonetheless, our findings are consistent with recent studies showing that asymmetric Notch activity in sibling cells is critical for generation of asymmetric cell divisions in the developing cortex and neural tube (Bultje et al., 2009; Das and Storey, 2012; Dong et al., 2012).

Intralineage and directional Notch signaling occurring between sister cells apparently plays a key role in the generation of asymmetric divisions in zebrafish radial glia (Dong et al., 2012). This is consistent with our finding that sister cells use Notch to assume asymmetric fates in clonal-density culture, although knowing whether this is the dominant mode of Notch signaling in vivo will depend on future studies using live imaging of Notch reporters.

In conclusion, we showed here that Numb function changes over time, regulating proliferation early and cell fate later. Interestingly, other genes controlling retinogenesis also show this type of functional switch. For example, Chx10 was reported to drive progenitor proliferation in the embryonic retina (Burmeister et al., 1996), whereas it has no effect on division later, and instead controls the photoreceptor and bipolar cell fate choice (Livne-Bar et al., 2006). It will be interesting in the future to determine whether there is a link between the functions of these factors with dual activities, and whether similar mechanisms might be regulating their functional switch during development.

\section{References}

Alexandre P, Reugels AM, Barker D, Blanc E, Clarke JD (2010) Neurons derive from the more apical daughter in asymmetric divisions in the zebrafish neural tube. Nat Neurosci 13:673-679. CrossRef Medline

Bani-Yaghoub M, Kubu CJ, Cowling R, Rochira J, Nikopoulos GN, Bellum S, Verdi JM (2007) A switch in numb isoforms is a critical step in cortical development. Dev Dyn 236:696-705. CrossRef Medline

Betschinger J, Knoblich JA (2004) Dare to be different: asymmetric cell division in Drosophila, C. elegans and vertebrates. Curr Biol 14:R674R685. CrossRef Medline

Buescher M, Yeo SL, Udolph G, Zavortink M, Yang X, Tear G, Chia W (1998) Binary sibling neuronal cell fate decisions in the Drosophila embryonic central nervous system are nonstochastic and require inscuteable-mediated asymmetry of ganglion mother cells. Genes Dev 12:1858-1870. CrossRef Medline

Bultje RS, Castaneda-Castellanos DR, Jan LY, Jan YN, Kriegstein AR, Shi SH (2009) Mammalian Par3 regulates progenitor cell asymmetric di- 
vision via notch signaling in the developing neocortex. Neuron 63: 189-202. CrossRef Medline

Burmeister M, Novak J, Liang MY, Basu S, Ploder L, Hawes NL, Vidgen D, Hoover F, Goldman D, Kalnins VI, Roderick TH, Taylor BA, Hankin MH, McInnes RR (1996) Ocular retardation mouse caused by Chx10 homeobox null allele: impaired retinal progenitor proliferation and bipolar cell differentiation. Nat Genet 12:376-384. CrossRef Medline

Cayouette M, Raff M (2002) Asymmetric segregation of Numb: a mechanism for neural specification from Drosophila to mammals. Nat Neurosci 5:1265-1269. CrossRef Medline

Cayouette M, Raff M (2003) The orientation of cell division influences cellfate choice in the developing mammalian retina. Development 130:23292339. CrossRef Medline

Cayouette M, Whitmore AV, Jeffery G, Raff M (2001) Asymmetric segregation of Numb in retinal development and the influence of the pigmented epithelium. J Neurosci 21:5643-5651. Medline

Cayouette M, Barres BA, Raff M (2003) Importance of intrinsic mechanisms in cell fate decisions in the developing rat retina. Neuron 40:897904. CrossRef Medline

Cayouette M, Poggi L, Harris WA (2006) Lineage in the vertebrate retina. Trends Neurosci 29:563-570. CrossRef Medline

Chen D, Pacal M, Wenzel P, Knoepfler PS, Leone G, Bremner R (2009) Division and apoptosis of E2f-deficient retinal progenitors. Nature 462: 925-929. CrossRef Medline

Das G, Choi Y, Sicinski P, Levine EM (2009) Cyclin D1 fine-tunes the neurogenic output of embryonic retinal progenitor cells. Neural Dev 4:15. CrossRef Medline

Das RM, Storey KG (2012) Mitotic spindle orientation can direct cell fate and bias Notch activity in chick neural tube. EMBO Rep 13:448-454. CrossRef Medline

Dho SE, French MB, Woods SA, McGlade CJ (1999) Characterization of four mammalian numb protein isoforms. Identification of cytoplasmic and membrane-associated variants of the phosphotyrosine binding domain. J Biol Chem 274:33097-33104. CrossRef Medline

Dong Z, Yang N, Yeo SY, Chitnis A, Guo S (2012) Intralineage directional notch signaling regulates self-renewal and differentiation of asymmetrically dividing radial glia. Neuron 74:65-78. CrossRef Medline

Elliott J, Jolicoeur C, Ramamurthy V, Cayouette M (2008) Ikaros confers early temporal competence to mouse retinal progenitor cells. Neuron 60:26-39. CrossRef Medline

Farkas LM, Huttner WB (2008) The cell biology of neural stem and progenitor cells and its significance for their proliferation versus differentiation during mammalian brain development. Curr Opin Cell Biol 20:707-715. CrossRef Medline

Fish JL, Dehay C, Kennedy H, Huttner WB (2008) Making bigger brains-the evolution of neural-progenitor-cell division. J Cell Sci 121:2783-2793. CrossRef Medline

French MB, Koch U, Shaye RE, McGill MA, Dho SE, Guidos CJ, McGlade CJ (2002) Transgenic expression of numb inhibits notch signaling in immature thymocytes but does not alter $\mathrm{T}$ cell fate specification. J Immunol 168:3173-3180. Medline

Furukawa T, Mukherjee S, Bao ZZ, Morrow EM, Cepko CL (2000) rax, Hes1, and notch1 promote the formation of Muller glia by postnatal retinal progenitor cells. Neuron 26:383-394. CrossRef Medline

Gaiano N, Kohtz JD, Turnbull DH, Fishell G (1999) A method for rapid gain-of-function studies in the mouse embryonic nervous system. Nat Neurosci 2:812-819. CrossRef Medline

Gomes FL, Zhang G, Carbonell F, Correa JA, Harris WA, Simons BD, Cayouette M (2011) Reconstruction of rat retinal progenitor cell lineages in vitro reveals a surprising degree of stochasticity in cell fate decisions. Development 138:227-235. CrossRef Medline

Götz M, Huttner WB (2005) The cell biology of neurogenesis. Nat Rev Mol Cell Biol 6:777-788. CrossRef Medline

Guo M, Jan LY, Jan YN (1996) Control of daughter cell fates during asymmetric division: interaction of Numb and Notch. Neuron 17:27-41. CrossRef Medline

Hafler BP, Surzenko N, Beier KT, Punzo C, Trimarchi JM, Kong JH, Cepko CL (2012) Transcription factor Olig2 defines subpopulations of retinal progenitor cells biased toward specific cell fates. Proc Natl Acad Sci U S A 109:7882-7887. CrossRef Medline

Helms W, Lee H, Ammerman M, Parks AL, Muskavitch MA, Yedvobnick B (1999) Engineered truncations in the Drosophila mastermind protein disrupt Notch pathway function. Dev Biol 215:358-374. CrossRef Medline

Holt CE, Bertsch TW, Ellis HM, Harris WA (1988) Cellular determination in the Xenopus retina is independent of lineage and birth date. Neuron 1:15-26. CrossRef Medline

Huttner WB, Kosodo Y (2005) Symmetric versus asymmetric cell division during neurogenesis in the developing vertebrate central nervous system. Curr Opin Cell Biol 17:648-657. CrossRef Medline

Jadhav AP, Mason HA, Cepko CL (2006) Notch 1 inhibits photoreceptor production in the developing mammalian retina. Development 133:913923. CrossRef Medline

Jan YN, Jan LY (2001) Asymmetric cell division in the Drosophila nervous system. Nat Rev Neurosci 2:772-779. CrossRef Medline

Kammandel B, Chowdhury K, Stoykova A, Aparicio S, Brenner S, Gruss P (1999) Distinct cis-essential modules direct the time-space pattern of the Pax6 gene activity. Dev Biol 205:79-97. CrossRef Medline

Karaczyn A, Bani-Yaghoub M, Tremblay R, Kubu C, Cowling R, Adams TL, Prudovsky I, Spicer D, Friesel R, Vary C, Verdi JM (2010) Two novel human NUMB isoforms provide a potential link between development and cancer. Neural Dev 5:31. CrossRef Medline

Knoblich JA (2008) Mechanisms of asymmetric stem cell division. Cell 132: 583-597. CrossRef Medline

Li HS, Wang D, Shen Q, Schonemann MD, Gorski JA, Jones KR, Temple S, Jan LY, Jan YN (2003) Inactivation of Numb and Numblike in embryonic dorsal forebrain impairs neurogenesis and disrupts cortical morphogenesis. Neuron 40:1105-1118. CrossRef Medline

Livne-Bar I, Pacal M, Cheung MC, Hankin M, Trogadis J, Chen D, Dorval KM, Bremner R (2006) Chx10 is required to block photoreceptor differentiation but is dispensable for progenitor proliferation in the postnatal retina. Proc Natl Acad Sci U S A 103:4988-4993. CrossRef Medline

Marquardt T, Ashery-Padan R, Andrejewski N, Scardigli R, Guillemot F, Gruss P (2001) Pax6 is required for the multipotent state of retinal progenitor cells. Cell 105:43-55. CrossRef Medline

McGill MA, McGlade CJ (2003) Mammalian numb proteins promote Notch1 receptor ubiquitination and degradation of the Notch1 intracellular domain. J Biol Chem 278:23196-23203. CrossRef Medline

McGill MA, Dho SE, Weinmaster G, McGlade CJ (2009) Numb regulates post-endocytic trafficking and degradation of Notch1. J Biol Chem 284: 26427-26438. CrossRef Medline

Pece S, Confalonieri S, R Romano P, Di Fiore PP (2011) NUMB-ing down cancer by more than just a NOTCH. Biochim Biophys Acta 1815:26-43. Medline

Petersen PH, Zou K, Hwang JK, Jan YN, Zhong W (2002) Progenitor cell maintenance requires numb and numblike during mouse neurogenesis. Nature 419:929-934. CrossRef Medline

Petersen PH, Zou K, Krauss S, Zhong W (2004) Continuing role for mouse Numb and Numbl in maintaining progenitor cells during cortical neurogenesis. Nat Neurosci 7:803-811. CrossRef Medline

Postiglione MP, Jüschke C, Xie Y, Haas GA, Charalambous C, Knoblich JA (2011) Mouse inscuteable induces apical-Basal spindle orientation to facilitate intermediate progenitor generation in the developing neocortex. Neuron 72:269-284. CrossRef Medline

Rasin MR, Gazula VR, Breunig JJ, Kwan KY, Johnson MB, Liu-Chen S, Li HS, Jan LY, Jan YN, Rakic P, Sestan N (2007) Numb and Numbl are required for maintenance of cadherin-based adhesion and polarity of neural progenitors. Nat Neurosci 10:819-827. CrossRef Medline

Reugels AM, Boggetti B, Scheer N, Campos-Ortega JA (2006) Asymmetric localization of Numb:EGFP in dividing neuroepithelial cells during neurulation in Danio rerio. Dev Dyn 235:934-948. CrossRef Medline

Roegiers F, Jan YN (2004) Asymmetric cell division. Curr Opin Cell Biol 16:195-205. CrossRef Medline

Shen Q, Zhong W, Jan YN, Temple S (2002) Asymmetric Numb distribution is critical for asymmetric cell division of mouse cerebral cortical stem cells and neuroblasts. Development 129:4843-4853. Medline

Siller KH, Doe CQ (2009) Spindle orientation during asymmetric cell division. Nat Cell Biol 11:365-374. CrossRef Medline

Spana EP, Doe CQ (1996) Numb antagonizes Notch signaling to specify sibling neuron cell fates. Neuron 17:21-26. CrossRef Medline

Spana EP, Kopczynski C, Goodman CS, Doe CQ (1995) Asymmetric localization of numb autonomously determines sibling neuron identity in the Drosophila CNS. Development 121:3489-3494. Medline

Turner DL, Cepko CL (1987) A common progenitor for neurons and glia 
persists in rat retina late in development. Nature 328:131-136. CrossRef Medline

Turner DL, Snyder EY, Cepko CL (1990) Lineage-independent determination of cell type in the embryonic mouse retina. Neuron 4:833-845. CrossRef Medline

Verdi JM, Bashirullah A, Goldhawk DE, Kubu CJ, Jamali M, Meakin SO, Lipshitz HD (1999) Distinct human NUMB isoforms regulate differentiation vs. proliferation in the neuronal lineage. Proc Natl Acad Sci U S A 96:10472-10476. CrossRef Medline

Viatour P, Ehmer U, Saddic LA, Dorrell C, Andersen JB, Lin C, Zmoos AF, Mazur PK, Schaffer BE, Ostermeier A, Vogel H, Sylvester KG, Thorgeirsson SS, Grompe M, Sage J (2011) Notch signaling inhibits hepatocellular carcinoma following inactivation of the RB pathway. J Exp Med 208:1963-1976. CrossRef Medline

Wilson A, Ardiet DL, Saner C, Vilain N, Beermann F, Aguet M, Macdonald HR, Zilian O (2007) Normal hemopoiesis and lymphopoiesis in the combined absence of numb and numblike. J Immunol 178:6746-6751. Medline
Yaron O, Farhy C, Marquardt T, Applebury M, Ashery-Padan R (2006) Notch 1 functions to suppress cone-photoreceptor fate specification in the developing mouse retina. Development 133:1367-1378. CrossRef Medline

Zhong W, Chia W (2008) Neurogenesis and asymmetric cell division. Curr Opin Neurobiol 18:4-11. CrossRef Medline

Zhong W, Jiang MM, Schonemann MD, Meneses JJ, Pedersen RA, Jan LY, Jan YN (2000) Mouse numb is an essential gene involved in cortical neurogenesis. Proc Natl Acad Sci U S A 97:6844-6849. CrossRef Medline

Zhou Y, Atkins JB, Rompani SB, Bancescu DL, Petersen PH, Tang H, Zou K, Stewart SB, Zhong W (2007) The mammalian Golgi regulates numb signaling in asymmetric cell division by releasing ACBD3 during mitosis. Cell 129:163-178. CrossRef Medline

Zigman M, Cayouette M, Charalambous C, Schleiffer A, Hoeller O, Dunican D, McCudden CR, Firnberg N, Barres BA, Siderovski DP, Knoblich JA (2005) Mammalian inscuteable regulates spindle orientation and cell fate in the developing retina. Neuron 48:539-545. CrossRef Medline 